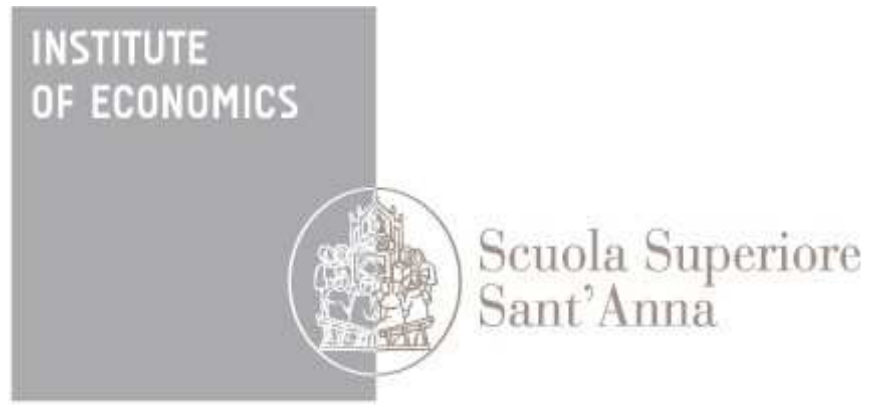

LEM | Laboratory of Economics and Management

Institute of Economics

Scuola Superiore Sant'Anna

Piazza Martiri della Libertà, 33 - 56127 Pisa, Italy ph. +3905088.33 .43$

institute.economics@sssup.it

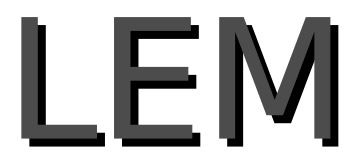

Working Paper Series

\title{
Labour market reforms in Italy: evaluating the effects of the Jobs Act
}

\author{
Marta Fana ${ }^{\circ}$ \\ Dario Guarascio * \\ Valeria Cirillo * \\ Institute d'Etudes Politiques de Paris \\ * Institute of Economics, Scuola Superiore Sant'Anna, Pisa, Italy
}




\title{
Labour market reforms in Italy: evaluating the effects of the Jobs Act*
}

\author{
Marta Fana ${ }^{\mathrm{a}}$, Dario Guarascio ${ }^{\mathrm{b}}$ and Valeria Cirillo ${ }^{\mathrm{b}}$ \\ anstitut d'Etudes Politiques de Paris

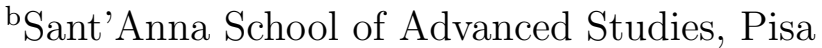

\begin{abstract}
Law 183 of 2014, evocatively named the 'Jobs Act', has determined a deep change in the Italian industrial relations. Bringing at completion a reform process begun in the 1990s, the Jobs Act has introduced a new contract type - 'contratto a tutele crescenti' - implying a substantial downsize of obligation for workers' reinstatement in case of firms invalidly firing them. The new permanent contract is therefore deprived of the substantial requirements of an open-ended contract. The Law has also weakened the legal constraints for firms intending to monitor workers through electronic devices and introduced new incentives for firms using temporary contracts. This article frames the Jobs Act within the overall labour market reform process occurred in Italy since mid-nineties and provides a first evaluation of its impacts on the Italian labour market. Taking advantage of different data sources (administrative and labour force data) and concentrating the analysis over the period after the Jobs Act implementation, the investigation provides the following results: the expected boost in employment growth is not detected; an increase in the share of temporary contracts over the open-ended ones is observed; a raise of part-time contracts within the new permanent positions emerges. The analysis shows that the Jobs Act failed in achieving its main goals. We discuss the observed evidence evaluating the appropriateness of the Law 183/2014 in the present Italian economic context accounting, in particular, for the structural effects of the recent crisis.
\end{abstract}

*Acknowledgements: This paper is produced as part of ISIGrowth project on Innovationfuelled, Sustainable, Inclusive Growth that has received funding from the European Union's Horizon 2020 research and innovation programme under grant agreement No. 649186 - ISIGrowth. The authors wish to thank Giovanni Dosi, Mario Pianta and Maria Enrica Virgillito for their comments and suggestions. All the usual disclaimers apply. 


\section{Introduction}

The Law 183 introduced in 2014 by the Italian government, evocatively named the 'Jobs Act', has determined a deep change in the industrial relations. A change towards a substantial liberalization of the labour market which brought to completion a reform process begun in the mid nineties. The key features of the Jobs Act are the following: i) a new contract type has been introduced for new hires - 'contratto a tutele crescenti' -, removing any form of obligation for workers' reinstatement in case of firms invalidly firing them, ii) the weakening of the legal constraints for firms intending to monitor workers through electronic devices of various kinds, iii) the use temporary contracts is facilitated by the elimination of previous restrictions on their adoption - before the Jobs Act implementation, firms were allowed up to a maximum of $20 \%$ temporary over the total amount of contracts. The crucial change regards the new open-ended contract, the 'contratto a tutele crescenti', designed to become the prevalent contract in the Italian labour market. The latter, in fact, is only nominally permanent since it allows extremely cheap (for firms) layoffs depriving workers of the reinstatement right. Moreover, just before the introduction of the new contract, a substantial monetary incentive - lasting three years and taking the form of a reduction in firms' social contributions burden per employee has been provided to firms hiring under a permanent contract or transforming other contracts into permanent ones. Thus, a contradiction emerges between Law 183/2014's declared intention - stimulating permanent employment - and its outcome - encouraging the diffusion of a contract type which allows extremely easy layoffs.

Considering the previous set-up characterizing the Italian industrial relations, the Jobs Act constitutes a dramatic turn towards a scheme where workers' protections are substantially downsized. For this reason, Law 183/2014 raised a lively debate in the country, at both the scientific and the political level. However, the government advertised the Jobs Act as one of the fundamental pillars of its anti-crisis action. An action aimed at re-boosting the economy and, in particular, at reducing unemployment and precariousness. Analogously to most of the other European economies, Italy has chosen labour market liberalization as one of the key policies to foster employment, productivity and competitiveness. Such policy strategy is largely based on mainstream theories identifying labour market 'rigidities' - namely, strong trade unions, generous social benefits, high minimum wages, powerful insiders, or firing restrictions - as the main causes behind persistent unemployment, inefficient factors allocation, mismatching between labour demand and supply and, in more general terms, weak competitiveness performance (Howell et al. (2007) and Kleinknecht et al. (2014)).

In this respect, the Italian case turns out to be a revealing one. Due to the combined persistence of high unemployment - particularly women and young people unemployment - and low productivity, the debate around the need for a substantial labour market reform has come to the fore since the early 1990s. The need for a change in terms of a greater freedom for firms - freedom to fire workers without onerous constraints and to bargain wages at the firm level rather than at the national one - prevailed among the different positions emerged in the debate. As a consequence, beginning in 1997, a constant and coherent set of norms have been gradually introduced leading to an increasingly liber- 
alized labour market. Nevertheless, despite easier firings, new temporary and flexible contractual forms, incentives for firm level bargaining, the dynamics of employment and productivity did not seem to be relevantly reshaped along the reforms period. In particular, liberalizing the labour market has resulted ineffective to solve three specific and long lasting structural Italian diseases: the under-representation of women and young people in the labour market; the North-South dualism with the South lagging behind in terms of employment rates and industrial production; the overall weak Italian productivity dynamics compared to its main competitors.

The 2008 economic crisis has strongly affected the Italian economy as well as the other Southern European ones. Major losses have been experienced both in terms of industrial production and employment. ${ }^{1}$ Furthermore, a worrisome contraction of the overall productive capacity - particularly in manufacturing industries - has been observed in Italy suggesting the occurrence of structural effects. The Italian industrial capacity dropped near to the $25 \%$ between 2008 and 2013 and a trend of persistent unemployment has hit the workforce all across sectors (Mazzucato et al. (2015) and Cirillo and Guarascio (2015)). This drop in production and employment renewed the mainstream consensus for structural reforms and, specifically, for a definitive labour market liberalization. In this light, the Jobs Act has been introduced - following a previous intervention in 2012 - with two aims: take on the massive unemployment mounting after the crisis (short run effect); strengthen the Italian competitiveness (medium-long run effect). Nevertheless, the effectiveness of labour market liberalization as a policy tool able to sustain growth, high productivity and high quality employment has been strongly disputed. In fact, diverging from the mainstream hypothesis a large part of the economic literature supported the thesis of a negative relationship between liberalization and labour productivity. Similarly, a negative effect of liberalization on long-term employment - with long-term employment considered crucial for the diffusion of knowledge and innovation within the economy - has been identified in the same literature.

This work aims to analyse the impacts of the Jobs Act on the Italian economy. The analysis focuses on the Jobs Act as a part of the whole reform process which took place in Italy from early nineties until today. Moreover, the dynamics of key economic variables detected along the reform process - allowing to appreciate labour market structural features, the economic context in which reforms were implemented as well as the economy's response according to the outcome of the proposed data inspection - is also provided to complete the picture. The main contribution regards the analysis of the impact on employment of Law 183/2014, carried out using both labour force and administrative data to account for stock and flow variations in employment, contracts' type as well as for their distribution across sectors, age cohorts and gender.

The goal of the statistical analysis is, therefore, threefold: first, we investigate whether the reduction in permanent contracts' costs leads to higher permanent

\footnotetext{
${ }^{1}$ The unemployment rate in Italy passed from $6.7 \%$ in 2006 to $12.7 \%$ in 2014 ; over the same period, the GDP dropped by $7.1 \%$ (Data source: Eurostat). Latest institutional reports and forecasts are not rosy even for the 3-year period upfront. According to the Oecd Economic Outlook 2015, even in 2017 the Italian unemployment rate will be one of the highest in the Euro Area, at 11\%. The expected recovery in GDP growth, foreseen at $1.7 \%$ in 2017, won't be able to stimulate aggregate demand which will continue to lack well beyond its pre-crisis level.
} 
employment reducing atypical jobs, measured as the share of total temporary employment on total dependent employment. Second, we analyse to which extent Jobs Act - and its ancillary policies - contributes to employment growth. ${ }^{2}$ Finally, we discuss whether the employment effects of Law 183/2014 are likely to affect growth and productivity in the medium and long run.

The article is organized as follows. In section 2 , we revise the literature which analyses the effect of labour market flexibility on job creation and productivity. In section 3, we introduce the Italian case focusing on some key stylized facts and summarizing the main features of the reform process begun in 1997. Section 4 focuses on the last reform of the the Italian labour market - The Jobs Act - and provides a first evaluation of its impact on employment. Section 5 concludes reporting some final remarks.

\section{Employment, productivity and labour market deregulation: a review of the literature}

Since the eighties, the policy recipe adopted in Europe to increase competitiveness and reduce unemployment has been largely based on labour market liberalization. Founded on a neoclassical interpretation of the economy, labour market liberalization has been conceived as the key instrument to remove or soften market 'rigidities'. Rigidities held responsible, according to mainstream theories, of hampering (labour) market clearing, preventing efficient factors allocation and avoiding social welfare maximization. Examples of such rigidities are strong trade unions, generous social benefits, high minimum wages, powerful insiders or firing restrictions (Howell et al. (2007); Kleinknecht (1998), and Kleinknecht et al. (2014)). Particularly, employment protection has been increasingly seen as an obstacle to job creation due to high costs of dismissals (Lazear (1990); Scarpetta (1996); Siebert (1997); Elmeskov et al. (1998); Blanchard and Wolfers (2000); Saint-Paul (2004) and Nickell et al. (2005)). Accordingly, many forms of employment protection have been identified as the major cause of longer spells of unemployment as in Blanchard and Portugal (2001).

Grounded on these theoretical foundations, a set of reform interventions - popularised as 'structural reforms' - have been implemented in Europe from the early nineties onward. The standard reform set-up consists in lifting firing restrictions, reducing minimum wages, cutting back social benefits and encouraging firm-level bargaining (Kleinknecht et al. (2014)). The main arguments according to which a relatively more liberalized labour market would spur jobs and competitiveness can be summarized as follows.

First, the presence of strong firing protections is expected to avoid an efficient reallocation of workers among sectors. Therefore, theories supporting structural reforms - intended, in a supply side perspective, as the need for deep market liberalization - claim that firing protections prevent labour market matching, making more difficult for workers to find the job in which they are more productive (Abraham and Taylor (1993); Bentolila and Saint-Paul (1994) and Boeri and Garibaldi (2007)). ${ }^{3}$ Second, large unemployment benefits are expected to work

\footnotetext{
${ }^{2}$ In order to exhaustively evaluate the Jobs Act effects, a set of parallel interventions aiming at effectively enforcing the main Law must be taken into account (Pini (2014))

${ }^{3}$ Overall, contributions purported to highlight the benefits related to labour market liberalization rely on the idea that a flexible labour market is the only way to allow a continuous
} 
as a disincentive to find and take a job, especially for young workers (OECD (1994)). ${ }^{4}$ Third, as argued by Bassanini and Ernst (2002) and Scarpetta and Tressel (2004), expensive firings are supposed to negatively affect productivity by reducing firms' willingness to introduce labour saving innovations.

An alternative and large strand of literature challenged the thesis supporting the need for structural reforms and labour market liberalization (see, among the others, Kleinknecht (1998); Lucidi and Kleinknecht (2009); Vergeer and Kleinknecht (2014) and Kleinknecht et al. (2014)). From an empirical point of view, Howell et al. (2007) highlighted the fragility of available econometric evidences which found a positive impact of labour market liberalisation on employment, productivity and innovation dynamics. The author identified a number of major shortcomings in the empirical literature he reviewed: i) the large use of data interpolation to build the time series adopted in the analysis - interpolations needed to obtain a reasonable number of time observations which raises doubts on the robustness of the existing results, ii) the statistical reliability of the labour market protection indicators (EPL) used in the same analysis, iii) the presence of potential biased stemming from a 'theory-driven' interpretation of the labour market in which institutions, power asymmetries and tacit knowledge are completely neglected.

On similar lines, Baker et al. (2005) and Avdagic (2013) show - re-examining the relationship between unemployment and labour market institutions - that many findings in the empirical literature which supports liberalization are sensible to changes in data, model specification and econometric techniques (Avdagic and Crouch (2015)). Moreover, Armingeon and Baccaro (2012) and Avdagic (2015) do not find a statistically significant relationship between employment protection and unemployment, while Oesch (2010) and Noelke (2011) do not find evidence at all regarding the link between employment protection and negative employment performance for low-skilled and young workers. ${ }^{5}$

As previously argued, Italy undertook, since the mid nineties, a path of reforms in which the liberalization of labour market played a fundamental role. These reforms were implemented to increase labour productivity and to foster employment participation. As recognized by Malgarini et al. (2013) and Mancini (2007), Italy represents indeed a case of special interest: the country's labour market institutions have dramatically changed since the nineties with a huge reduction of Employment Protection Legislation (EPL) for new hires. In particular, Italian policy makers were concerned by the weak performances - in terms of women and young people employment - compared to the other European economies. Thus, aiming at inverting such negative trends and following the theoretical framework described above, firing restrictions were softened, new forms of temporary contracts were introduced and firm level bargaining schemes

and efficient job turnover favouring knowledge and technological spillovers expected to boost productivity growth (Bassanini and Ernst (2002); Scarpetta and Tressel (2004); Battisti and Vallanti (2013); Cappellari et al. (2012); Damiani et al. (2014))

${ }^{4}$ The presence of a large unemployment benefit is expected to produce an increase in workers bargaining power which fosters wages growth leading to a contraction of labour demand Holmlund (1998)

${ }^{5} \mathrm{~A}$ number of empirical studies taking into consideration different time periods from the 1960s until today found no evidence of correlation between labour market liberalisation and innovation while, in many cases, the opposite is detected (Glyn et al. (2003); Howell et al. (2007); Lucidi and Kleinknecht (2009); Vergeer and Kleinknecht (2012) and Kleinknecht et al. (2014)) 
encouraged (Lucidi and Kleinknecht (2009)).

Going hand in hand with the introduction of these liberalization measures, a number of contributions have examined, empirically, the outcomes of the reform interventions. In the case of Italy, the review of the literature provides heterogeneous evidence regarding the link between labour market liberalization, productivity dynamics and employment growth. However, a certain amount of convergence is detectable concerning the negative correlation between liberalization and labour productivity. In particular, Battisti and Vallanti (2013) empirically assessed the effects of flexibility - in terms of decentralized wage schemes and temporary forms of employment - on a sample of Italian firms evaluating the impact of the former on firm productivity. The authors found that the diffusion of temporary contracts reduces workers' motivation and effort pushing downwards labour productivity. Similar evidence has been found by Boeri and Garibaldi (2007) who detected a positive effect of temporary contracts on employment and a negative one on labour productivity.

On the employment side, many authors recognized the positive impact of labour market flexibilization on the Italian employment rate. As Lucidi and Kleinknecht (2009) pointed out, part of the employment gains experienced during the liberalization periods can be due to a transformation of informal jobs in regular ones - a phenomenon traditionally affecting the Italian economy. ${ }^{6}$ Furthermore, the virtuous link connecting labour market liberalization and employment performance is less evident when women and young people are explicitly included in the analysis. In fact, the growth of women employment detected in Italy between 1995 and 2006 has seen women remaining in an unfavourable position compared to males. Conversely, young people employment shown positive performance along the reform period but resulting largely in an increase of temporary contracts.

Another relevant dimension in the analysis of the impact of labour market reforms in Italy regards the North-South regional dualism affecting the country. The literature which investigated the impact of labour market reforms in Italy underlined the relevance of such dualism. The positive employment dynamics detected during part of the liberalization period have been unequally distributed across Italian regions. Specifically, the traditional North-South divide has increased over the reform period with the larger part of the job creation effect attributed to the effects of liberalization measures - experienced in the North while the South lagged behind especially with respect to women and young people participation into the labour market (Lucidi and Kleinknecht (2009)).

On the productivity side, there is a consensus on the existence of a negative relationship linking liberalization and productivity performances in Italy (Faini and Sapir (2005); Ciriaci and Palma (2008); Lucidi and Kleinknecht (2009); Codogno (2009) and Jona-Lasinio and Vallanti (2013)). Daveri et al. (2005), for example, attributed the Italian poor labour productivity performance to an inflow into employment of low skilled workers. Focusing on the Italian case, Boeri and Garibaldi (2007) found a negative relation between temporary employment and productivity growth. Analogous results are in Addessi (2014) who detected a persistent negative effect of temporary contracts on workers

\footnotetext{
${ }^{6}$ Regarding the employment impact of liberalization, Lucidi and Kleinknecht (2009) found that between 1999-2006 the Italian unemployment rate fell by $4.9 \%$ compared to $3 \%$ fall in the EU15; while in the same period the employment rate increases by $7.6 \%$ compared with $6.3 \%$ in the EU15.
} 
productivity. Giving further support to this evidence, Cappellari et al. (2012) identified a negative effect of temporary employment on different productivity indicators exploiting a panel data on Italian firms.

The debate on the effects of labour market liberalization in Italy has recently come back to the fore due to the reform interventions adopted after the 2008's crisis (Cirillo and Guarascio (2015)). Pini (2012), Antonioli and Pini (2014) and Pini (2014) have discussed the rationale and the potential implications of the further labour market liberalization undergone during the crisis years (the authors focused their attention on the 2012 and the 2015's reform interventions). In their analysis, the authors raise doubts on the appropriateness of a new wave of labour market deregulation as a policy tool reliable to tackle Italian economy's structural problems. In particular, they refer to the rise of structural employment - especially in the Southern regions - and the persistent stagnation of productivity. Two negative trends exacerbated during the aftermath of the 2008 crisis. Pini (2014) argues that freeing firms from the remaining constraints in terms of labour regulations (i.e firing restrictions), would not help addressing these structural issues. On the contrary, the risks associated to such interventions are emphasized. In this sense, Pini (2014) stresses how further reductions in firing restrictions can, especially during deep recessions phases as the one experienced in Italy since 2008, deepen the state of economic depression penalizing the dynamics of consumption and internal demand.

In line with Pini (2014)'s arguments, Cirillo and Guarascio (2015) claimed that the adoption of cost competitiveness strategies in the EU periphery - with labour market liberalization identified as a key element of such a strategy - in order to recover competitiveness after the 2008's crisis risks, in turn, to be counterproductive and damaging. The authors identify in the lack of demand and investments - particularly innovative ones - the true Achille's heel of Southern EU's economies, recognizing how the recent labour market reforms provide perverse incentives to firms without tackling the economies' structural problems. The latter element is worsened further by the fact that previous liberalizations were completely ineffective in tackling such structural issues. ${ }^{7}$

In the next section we provide a picture of the Italian stylized facts concerning employment, productivity and innovation, going in depth about key Italian labour market features. The objective of this empirical picture is twofold: on the one hand, it offers a detailed diagnosis of the context in which labour market reforms were implemented; on the other, it allows to appreciate the performances - looking at relevant variables - of the Italian economy along the reform process. Beside this, we offer a synthesis of the cornerstone interventions featuring such reform process.

\footnotetext{
${ }^{7}$ Cirillo and Guarascio (2015) argue that softening firing restrictions during recession phases, as the Italian governments has done in 2012 and 2015, can have two major shortcomings: the downward push on internal demand due to potential reduction in employment and to the weakening of workers bargaining power; the incentive for firms to reduce cost through job destruction discouraging technological competitiveness strategies based on investments, training and organizational innovation.
} 


\section{The Italian case: stylized facts and the re- forms chronicle}

The reform process of the Italian labour market started at the beginning of the nineties with the introduction of wage bargaining decentralization and it lasted for several years. The implementation of the Jobs Act can be considered the last step of such process of labour market liberalization. A liberalization process representing the key policy chosen to face low productivity and weak employment dynamics (Lucidi and Kleinknecht (2009)). In this section, we aim to analyse the Italian labour market reform process shedding light on the structural economic background in which it took place. Therefore, after revise the main cornerstones of the reform process, we highlight some major stylized facts emerging as a consequence of it.

\subsection{Italian structural background}

During the whole reform period that started at the beginning of the nineties, Italy's employment rate as well as labour productivity figures lagged behind the ones of EU partners. In fact, the difference between EU15 and Italy's employment rate has been of ten percentage points over the entire period (in 1996 the employment rate in the EU was $60.1 \%$ and $50.1 \%$ in Italy while in 2013 it was respectively $65 \%$ and $55.5 \%$ ). Also Italian labour productivity growth stayed below the EU average (the EU rate in 1996-2013 has been of 1.4 while the Italian one was of 0.3$){ }^{8}$

Furthermore, from the nineties onwards the Italian labour market resulted to be affected by a number of structural weaknesses among which we identify three main elements (Saltari and Travaglini (2008)). First, Italian women participation into the labour market has been systematically lower in comparison with men figures. Second, young people employment remained strongly below the EU15 average over the entire period of labour market reforms implementation. Third, Italy has always been characterized by a deep geographical dualism: the North growing in terms of production, employment and productivity; the South lagging behind showing weak performances, particularly regarding young people and women participation in the labour market. Figure 1 highlights the dynamics of employment in Italy broken down by sex and macro-regions (North versus South).

Figure 1 provides a clear picture of the divide affecting the Italian labour market. The systematic difference between female and male employment rates emerges from the data. In 1992, men participation into the labour market overcomes the one of women of 30 percentage points in the South and of 10 percentage points in the North. At the beginning of 2015 such difference in gender participation remains strong even if reduced by a small amount for the effect of the 2008 economic crisis. $^{9}$

A description of the Italian weaknesses in terms of young people labour market

\footnotetext{
${ }^{8}$ Data source: authors' elaboration on Eurostat data.

${ }^{9}$ As highlighted in Calza Bini (2014) and Cirillo and Guarascio (2015) the last economic crisis has mostly impacted on male dominated industrial sectors such as construction and manufacturing. This phenomenon produced an apparent re-balancing in the male-female employment divide.
} 
Figure 1: Employment rate by sex and macro region

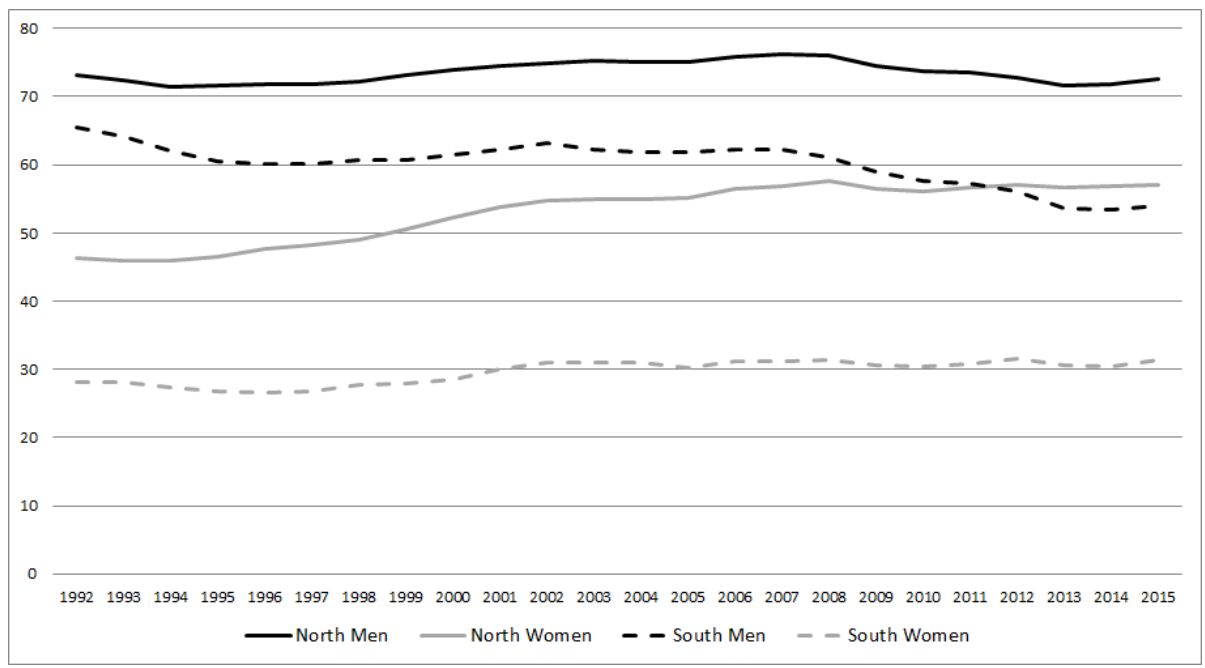

Data source: Italian Statistical Office - ISTAT

participation is presented in figure 2. Similarly to what has been shown regarding the male-female divide, Italian youngsters have experienced employment rates more than 10 percentage points below than the European ones. Moreover, the explosion of the crisis in 2008 has given rise to a further deepening of such divide. In fact, the difference between EU15 and Italy's young people employment rates is around 20 percentage points in $2015 .{ }^{10}$

The evidence reported in figures 1 and 2 shed light on a set of structural weaknesses affecting the Italian economy and, in particular, its labour market. Both at the beginning, as well as all along the reform period, these weaknesses remained persistent in terms of dynamics and intensity. In this respect, the decision to implement a process of labour market liberalization emerged from the strong debate concerning the proper policy strategy to face such structural challenges. Specifically, introducing temporary contracts, facilitating firings and giving incentives to decentralized wage bargaining was seen, specially by mainstream economists, as the main course of action to restart productivity and employment growth. With respect to the latter, temporary contracts were identified as an effective tool to facilitate young people entry into the labour market (Barbieri and Scherer (2009)).

\subsection{Reform Chronicle}

As stated above, the reform process started at the beginning of the nineties has given raise to some major policy interventions implemented in Italy to liberalize the labour market. Some main cornerstones can be detected. The first intervention dates back to 1983-84: the introduction of the so called training/work

\footnotetext{
${ }^{10}$ Authors' elaboration on Eurostat-LFS data.
} 
Figure 2: Employment rate of young people (15-24 years) in Italy and Europe (EU15)

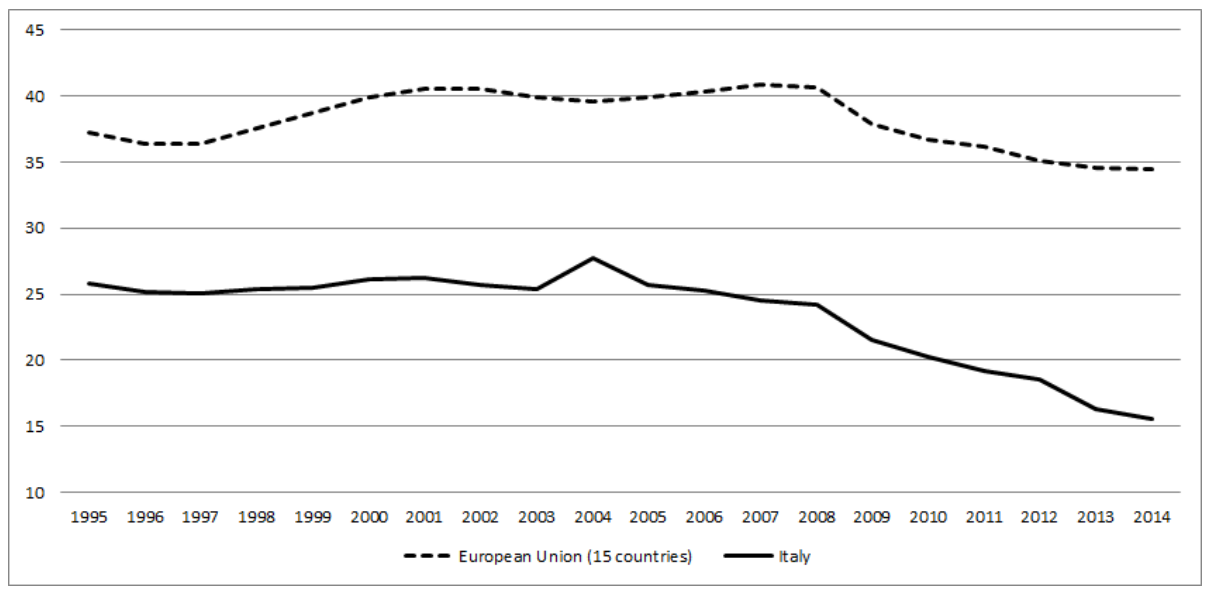

Data source: Eurostat

contracts. The latter are temporary working arrangements under which an employer assumes - with a fixed term - a young worker combining ad-hoc training cycles and work in the workplace. However, it is in the early 90s that the liberalization process accelerates with the introduction of new laws regarding collective firing and the definitive abolishment of the automatic indexation of wages to inflation. In 1993, a new collective bargaining structure was introduced organized on a national level for the adjustments of wages to inflation dynamics and on a firm/regional level for the regulation of productivity-related pay schemes (Jona-Lasinio and Vallanti (2013)). Nevertheless, the first big step in the process of labour market liberalization took place in 1997 with the so-called 'Pacchetto Treu' (law 196/1997). This law provided a new contractual framework introducing apprenticeship schemes, part-time employment, temporary contracts and creating also private temporary work agencies aimed at facilitating the matching between supply and demand in the labour market. In 2001, the Italian government extended the possibility and the terms for use of temporary contracts and in 2003, with the 'Legge Biagi' (Law n.30/2003), the use of staff-leasing contract, part-time work and non-standard reforms of employment relationships have been largely extended. After a period of relative calm in the reforms process, the 2008 crisis and its sharp consequences on Italian economy revived the debate concerning the need for further structural reforms. In 2012, the 'Legge Fornero' (law 92/2012) weakened the effectiveness of the 'Articolo 18 ' of the Law 300/1970. The latter was the mainstay of the previous Italian industrial relations set-up which used to strongly protect workers - enrolled with the open-ended contracts - from invalid lay-offs. However, Law 92/2012 only weakened the previous discipline protecting workers - namely, the Articolo 18 - without completely abolishing it. For a considerable set of cases, in fact, the obligation of recourse to the courts - in case of disputes over a dismissal - as well as the possibility of workers' reinstatement has been preserved. Nevertheless, a 
Table 1: Labour Market Reforms in Italy

\begin{tabular}{ll}
\hline & \multicolumn{1}{c}{ Reforms description } \\
\hline $1984-1987$ & $\begin{array}{l}\text { Introduction of part-time and training contracts } \\
\text { (1983-84) and reduction in the wage indexation }\end{array}$ \\
& $(1986)$. \\
New procedures for collecting firing, 'Giugni \\
agreement' (1993): introduction of the two-tiers \\
wage bargaining (centralized and at firm level) \\
and abolition of the indexation (1992); \\
Extension of the training contracts and the col- \\
laboration contracts are introduced (no firing and \\
hiring costs) to a wider range of situations \\
'Pacchetto Treu' (end of 1997): use of temporary \\
worker agency;new fiscal treatment of part-time \\
work. New atypical contracts such as job-sharing; \\
new fiscal treatment of part-time work. \\
Decree Law no. 368: Fixed term contracts are \\
extended to regular employees \\
'Legge Biagi (2003): which provides a common \\
framework to atypical contracts and extends fur- \\
ther the use of TWA' \\
'Legge Fornero' (Law 92/2012): two additional \\
forms of temporary employment; Art. 18 Law. \\
No. 300/1970 is amended \\
'Jobs Act' (Law 183/2014): revision of the unem- \\
ployment benefit system and introduction of the \\
contract with increasing protection.
\end{tabular}

definitive change has been determined with the Law object of this analysis, the Jobs Act. The latter has definitively abolished the protections stemming from the Articolo 18 of Law 300/1970 eliminating all the residual protections for all workers enrolled from the Jobs Act onward (a detailed analysis of the Jobs Act as well as a first evaluation of its impacts are provided in the next section).

Summing up, the reforms implemented over the last decade in Italy determined a large 'flexibilization' of the labour market both in the use of atypical contractual arrangements and in the decentralization of the bargaining process. Labour market reforms liberalize the use of temporary form of employment while the firing rules on regular contracts have been gradually softened until the recent and definitive intervention with the Jobs Act. Table 2 summarizes the reform path listing the main reforms applied to the Italian labour market over the last decades.

\subsection{Stylized facts}

The implementation of the reform process has led to some main consequences that can be summarized in at least five points. First, the overall stock of temporary employment has increased from 8 to $14 \%$ of total employment as it is detectable looking at values on the y axis (left hand side) in figure 3. As expected, this change has mainly characterized new entrants in the labour market proxied by younger cohort (15-24 years old). Remarkably, the share of young people employed with a temporary contract tripled from $20 \%$ to $60 \%$ over the entire period (figure 3, right hand side of the y axes). Generally speaking, temporary employment seems to be constantly increasing in the Italian labour market - the share of involuntary temporary employment corresponds to $9.9 \%$ in 2014 and almost all temporary employment is involuntary. 
Figure 3: Share of temporary employment on total employment by age groups



Data source: Italian Statistical Office - ISTAT

The tight link between age cohorts and temporary contracts is shown in figure 4. The 20-29 age cohort, in fact, is characterized by a substantially higher share of temporary contracts if compared to the other age cohorts.

A related dynamics regards the relationship between use of temporary contracts and job duration, as emerge in figure 5. Among temporary contracts, the proportion of short-term contracts lasting less than 6 months has sharply increased over time.

More in detail, the share of temporary employment covered by short-term contracts between 1 and 6 months has substantially increased over time representing almost $40 \%$ of total temporary employment in 2015 . Within this category, more than $30 \%$ is due to contracts lasting within a week (Data source: authors elaboration on Italian Ministry of Labour data). Second, the employment protection indicator measuring the strictness of regulation on the use of fixed-term and temporary work agency contracts decreased from 5.25 in 1985 to 2 in 2012 for temporary employment remaining almost constant over time for regular contracts - 2.76 - (Data source: OECD/IDB Employment Protection Database). From this point of view, the Italian labour market reform has contributed to create a dual labour market where fixed-term contract - which until 2014 were characterized by a high level of protection against layoffs - started to co-exist with temporary employment - characterized, in turn, by low level of protection. Third, in Italy the workforce skill structure has been characterized by job creation in high skills and low skills groups depicting a smoothed trend toward polarization. Contrary to the European trend of upskilling - Managers, Associate Professionals, Technicians and Clerks grow by more than $1 \%$ by year over the entire period (2000-2013) - in Italy job creation is concentrated both in the upper and bottom part of the skill distribution - proxied by the International Standard Classification of Occupations (ISCO) - (Hurley et al. (2013)). 
Figure 4: Temporary contracts by modal age

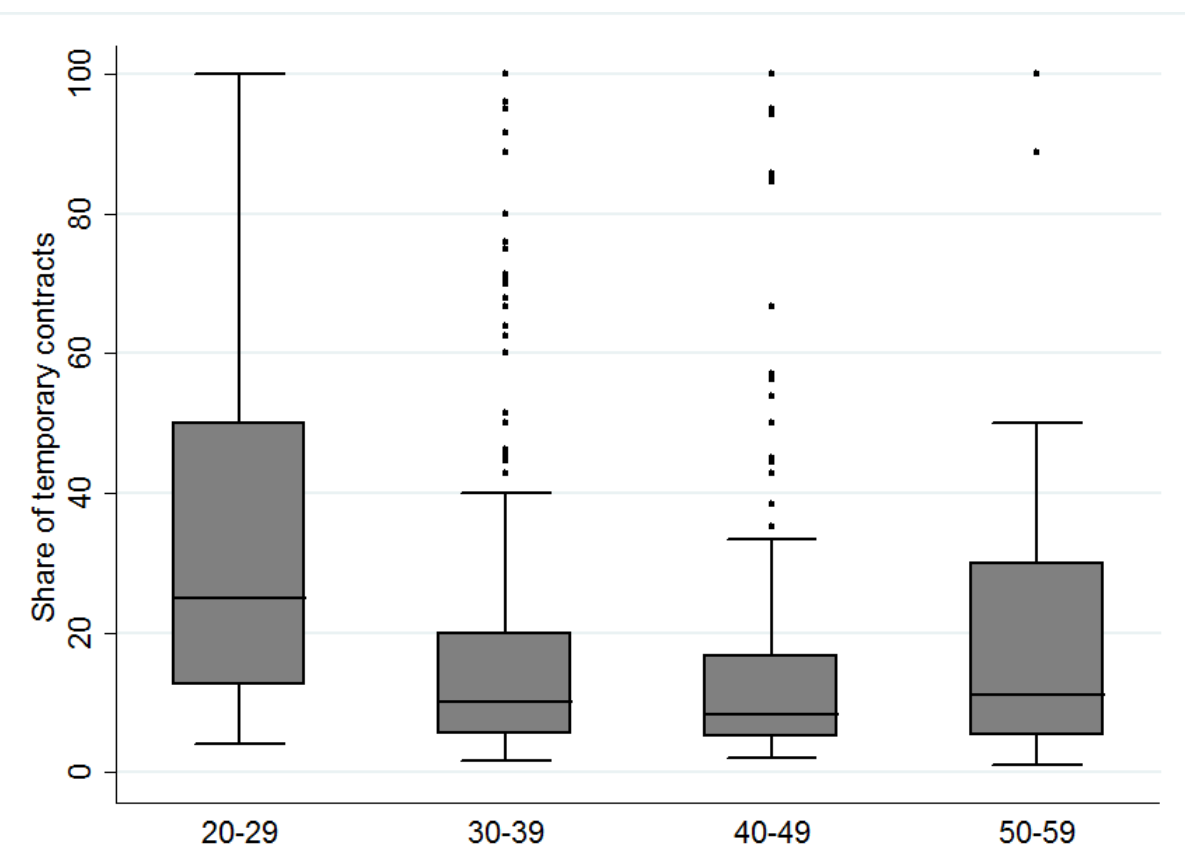

Data source: Structure of Earnings Survey, 2010, Italy - Eurostat

Figure 5: Share of temporary employment by duration of labour contract

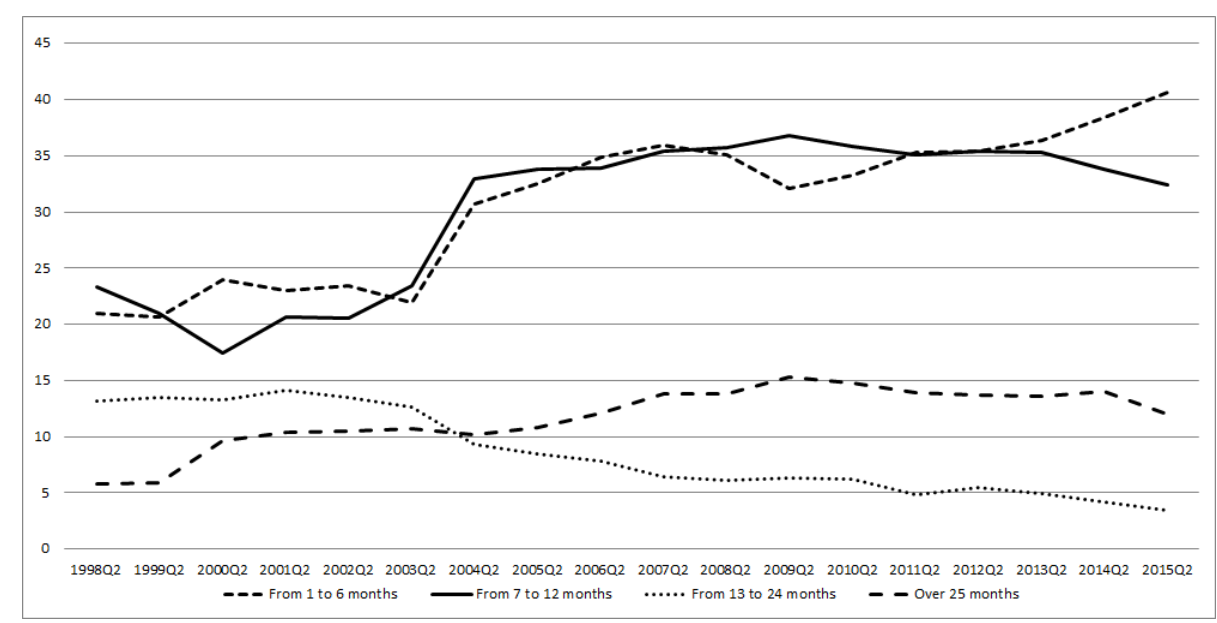

Data source: Labour Force Survey - Eurostat

As figure 6 underlines, over the period 2000-2014, Managers, Technicians and Associate Professionals - proxying high paid and high qualified jobs - have grown 
Figure 6: Change in employment by professional group (2000-2013)

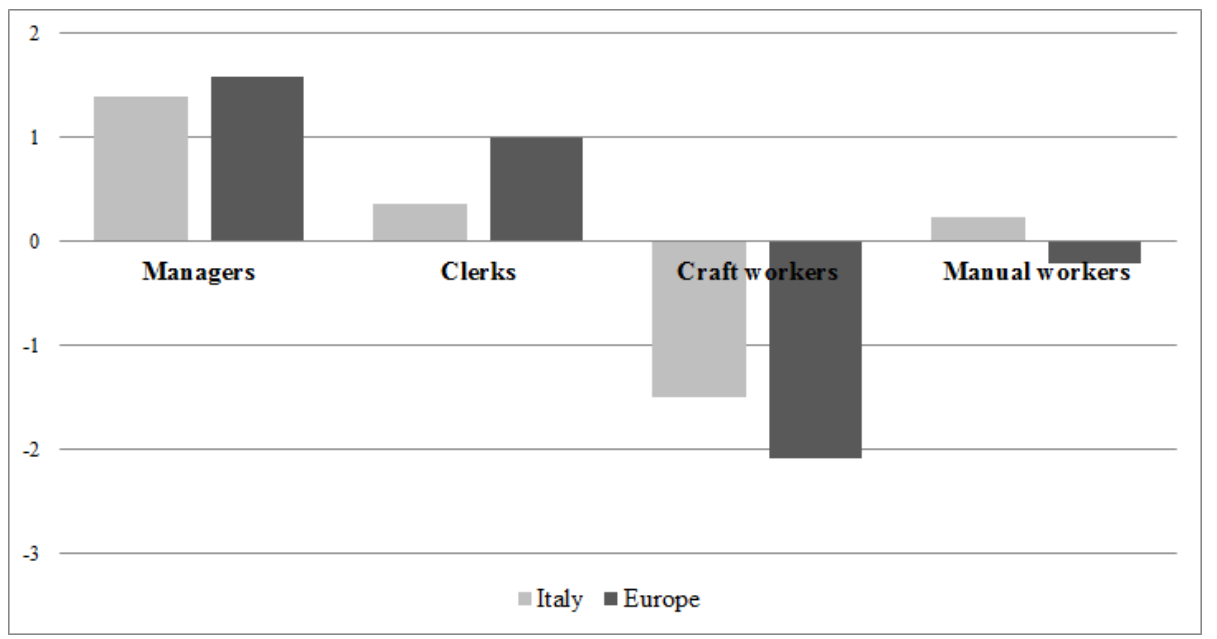

Data source: Labour Force Survey - Eurostat

by $1.5 \%$ by year, Clerks by more than $1 \%$ and Manual workers - proxying low paid and low qualified professions - by $0.5 \%$. The growth of the latter has been mainly registered in low-tech services, mostly related to retail trade, tourism, childcare, elderly, etc. Conversely, both in Europe and Italy, Craft workers decreased by almost $1 \%$ per year. ${ }^{11}$

Fourth, the reform process does not intervene on the unemployment to inactivity transition which remains above the European mean by almost twenty percentage points since 2010. On the contrary, the transition to employment not only stayed below the European mean, but even decreases - from $18 \%$ in the third quarter of 2010 to $11 \%$ in the second quarter of $2015 .{ }^{12}$ Overall, labour market flows for Italy suggests a deterioration of labour market participation with a transition towards inactivity, probably due to long unemployment spell. Finally, in aggregate terms, labour productivity has been declining over the entire reform period, by on average $0.1 \%$ and being, since 2000 , constantly below the European average (Source: Eurostat). The causes behind Italian labour productivity weak performances have been deeply investigated in the empirical literature. Ciriaci and Palma (2008) and Faini and Sapir (2005) identified the existence of a potential relationship between productivity dynamics and the reform process implemented over the last decade. As argued, among the others, by Simonazzi et al. (2013), Landesmann (2013) and Cirillo and Guarascio (2015), productivity is strongly linked with the dynamics of R\&D expenditure and investments (particularly innovative ones). The Italian data show that ex-

\footnotetext{
${ }^{11}$ Following Cirillo et al. (2014), we aggregate ISCO categories as follows: managers, professionals and technicians in the "managers" group; clerk workers and service workers in the "clerks" group; craft workers and skilled agricultural workers in the "craft workers" group; and manual workers and elementary occupations in the "manual" group. The aggregation into these four groups reflects educational and wage ranks of ISCO88. For a detailed analysis on employment by skills in Europe, see Cirillo et al. (2014)

${ }^{12}$ Data Source: Eurostat - 2010 is the first available point in time in Eurostat series.
} 
penditure on R\&D activities has been mostly stagnant both in the government sector - from $0.2 \%$ in 1995 to 0.19 in 2014 - and in the business enterprise sectors - from 0.5 to 0.72 - suggesting a turn toward more cost-competitiveness strategies based on labour cost reduction and leading to an impoverishment of the productive structure (Source: Eurostat). Overall, Italy expenditure on R\&D activities has constantly been below the EU average making harder, especially for manufacturing sectors, to be successful in international competition and to be resilient during the recession following 2008's crisis. ${ }^{13}$

The evidence regarding the dynamics of Italian aggregate R\&D expenditure over the liberalization period helps to understand the economic context in which labour market have been put forth. As argued, the contemporaneous occurrence of $R \& D$ weakening and sharp deregulation in industrial relations suggests a general shift towards cost competitiveness strategies. Cirillo and Guarascio (2015) suggest that such shift is partly associated to the incentive towards wage compression and job destruction stemming from the recent labour market reforms. ${ }^{14}$ Framing on the proposed general picture, the next section describes the main changes introduced by the last reform - The Jobs Act - providing a first empirical evaluation of its impacts on the Italian economy.

\section{The Jobs Act}

All the Italian governments in charge after 2011, have had as a primary objective a further liberalization of the labour market, defined as key priority within the set of structural reforms, required by the European Commission, IMF and ECB under the fiscal adjustment plans. The Law 183/2014 - the 'Jobs Act' - reformed both the 'open-ended' contract as well as some of the atypical ones. ${ }^{15}$ We briefly summarize some key components of the reform which deserve to be underlined.

- The new standard for open-ended contracts: Contratto a tutele crescenti. A new contract type has been introduced for new hires - 'contratto a tutele crescenti' -, which does not provide any form of obligation of workers' reinstatement in case of firms invalidly firing them, unless the lay-off is based on discrimination or it is communicated orally. Conversely, firms are obliged to reimburse workers - in case of invalid lay-off - with an amount equal to two wages per each year of work tenure and not less than four wages. In this way, workers are deprived of the protection represented - until the Jobs Act's introduction - by the possibility of court's referral and, more relevantly, of obtaining the reinstatement. Moreover, in the case of small firms (less than 15 employees) the compensation is halved. The new law actually abolished the standard open-ended contract, dismissing the substantial requirement of a permanent labour relationship, since workers could be arbitrarily fired without any economic causes. This

\footnotetext{
${ }^{13}$ The figures regarding trend of Italian $\mathrm{R} \& \mathrm{D}$ expenditure over time are reported in the Appendix

${ }^{14}$ Relying on a sectoral level analysis, Lucchese and Pianta (2012) explore the way economic cycles influence the relationship between innovation and employment in manufacturing industries and document how, in upswings, employment change is affected by new products, exports and wage growth, while during downswings new processes contribute to restructuring and job losses.

${ }^{15}$ The reform also modifies unemployment benefits which we do not discuss here.
} 
element constitute a strong reshape of the balance between workers and firms in the bargaining process and more importantly it abolish the standard open-ended contract from the Italian industrial relations.

- Electronic monitoring. The Jobs Act gives firms the faculty to monitor employees through many kinds of electronic devices. The latter intervention - strongly criticized for the risk of damaging privacy as well as workers' individual freedoms - is aimed at 'improving workers productivity'.

- Temporary contracts. The Jobs Act abrogates workers' right to get a permanent contract if the employers exceeds the limit of temporary contacts - as fraction of permanent ones, previously set at $20 \%$ - allowed for each firm. This implies that temporary contracts became cheaper for firms. This norm follows the so called Decreto Poletti, introduced in May 2014 , deleting the substantial requirements allowing the use of temporary contracts (i.e. temporary substitution of absent employees; temporary shock in production; etc...).

- Vouchers. Vouchers are hourly tickets, used to compensate workers, where the net hourly salary amounts to 7.5 euros, introduced in 2003 but implemented only since 2008. They have been introduced for 'accessory jobs'. ${ }^{16}$ The Jobs Act increases the maximum amount of revenues, from 5,000 until 7,000 euros, that could be received in vouchers. This regime strikes with the original aim of this job relationship because of the risk of being used for dependent work and not accessory one. In particular, workers under this kind of job relationship do not have any social security right, while they have only a minimal social security contribution, threatening the sustainability of the social security system itself.

Finally, in order to understand the preliminary results of the new law, presented in the next section, we need to highlight that under the Budgetary Law 2015, the Government introduced a substantial monetary incentive for firms hiring workers with the new type of open-ended contract. Each firm, hiring - between the 1st of January and the end of 2015 - a worker under a permanent contract (including all transformations from a temporary to a permanent job), is exempted to pay contributions to social security up to 8,060 euros per year for three years. Thus, such incentive is expected to stimulate the diffusion of open-ended contracts. It is worth to mention, however, that these new open-ended contracts are such only nominally permanent since they introduce the allow extremely cheap (for firms) layoffs and deprive workers of the reinstatement right. Thus, there it seems to be a contradiction between the declared intentions of the Law - stimulating permanent employment - and its outcome - diffusing a contract type allowing easy layoffs. Furthermore, the effective novelty is that monetary incentives are no longer targeted to specific groups (i.e.long-term unemployed persons, young, disabled people, women) or industries. Therefore, the new strategy does not seem to be made upon a 'growth oriented' policy, stimulating more efficient sectors or new employment, even for those vulnerable groups suffering from structural low employment rate and longer unemployment spells. As a further general remark, another potential contradiction - which clearly emerges

\footnotetext{
${ }^{16}$ The Italian version of the German mini-jobs
} 
from the empirical analysis which follows - between the rational and the motivation behind the incentive scheme and the Jobs Act. The latter, in fact provide - in combination with the effects of the previous 'Decreto Poletti' a relevant incentive for the use of temporary contracts. In this sense, the expected effect of the highly generous incentive scheme - increasing the share of open-ended contracts - risks to be, at least partially, counterbalanced by the opposite incentive towards temporary contracts contained in the Jobs Act.

The next section contains an empirical evaluation of the Jobs Act focusing on employment dynamics and discussing potential structural implications.

\subsection{A preliminary evaluation}

The Jobs Act have been introduced three months after the reduction in employers' contributions - 'de-contribution' - for new permanent contracts and contracts transformation from temporary to permanent ones. An empirical investigation aimed at completely disentangling the effect of the new reform from the impact of the de-contribution on employment is not possible, since the latter will end only in four years, where the counterfactual would emerge. Still, the dynamics of the labour market under the new legislative setting is detectable from both the statistical and the administrative data. The main data sources used for this analysis are:

- The Italian National Statistic Institute (Istat) database provides standard stock data on the labour force, divided into age groups and gender. Stock data include employment and unemployment statistics at the monthly, quarterly and annual level for dependent and independent workers. Sectoral contribution to employment is also provided as well as type of occupations, professions, within each industry. Other statistics are elaborated by the Eurostat Labour Force Survey

- The Ministry of Labour and Social Security Institute (INPS) databases provide administrative data on the flow of different type of contracts, activated, transformed and dismissed, for dependent and independent workers, excluding Agricultural sector and Public Administration (note: these data are not seasonally adjusted). Moreover, the Ministry of Labour database provides information on the duration of temporary contracts and a focus on the Youth Guarantee scheme; while the Social Security Institute database, in turn, offers information on atypical contracts as vouchers and, more importantly, on the number of contracts stipulated under the new fiscal regime for firms.

The goal of the statistical analysis is therefore threefold: first, we will investigate whether the reduction in the cost of permanent contracts is associated with an increase in permanent employment and, therefore, with a complementary reduction in atypical jobs measured as the shared of total temporary employment on total dependent employment. Second, we will investigate the contribution to employment due to other policies, like the European Youth Guarantee (EYG) implemented in 2014. Finally, we will discuss trends in atypical work emerging and the quality of this jobs in terms of potential growth and productivity.

The ability of the reform to generate new occupations could be investigated using both statistical and administrative data. Administrative data show that 
between January and July 2015, only the $20 \%$ of new hires have a permanent contract. $^{17}$ In particular, new permanent positions are only a minority even within permanent contracts, in fact, as shown in figure 7 most of them are represented by positions that have been transformed from a temporary to a permanent one. ${ }^{18}$ Furthermore, comparing both the dynamics of contracts activation and dismissal across the last two years, one can note a net increase in permanent contracts mainly due to the increase in activation while the rate of contracts dismissal is quite stable over the time span considered. The latter evidence shed light on the distress of the Italian labour market.

Second, the distribution of contracts by type of contract and working time (table 2 ) shows that part time jobs are more relevant among new permanent contracts than full time ones. ${ }^{19}$ More importantly, it comes out that during the second semester of 2015 , the incidence of involuntary part-time accounts for the $64,6 \%$ of the total part-time employment, according to Istat's quarterly report.

Finally, according to INPS, new hires under the 'contratto a tutele crescenti' earn a monthly wage $1.4 \%$ lower then the cohort hired one year before with the old open-ended contract. ${ }^{20}$

Figure 7: New permanent contracts and contract transformations in 2015

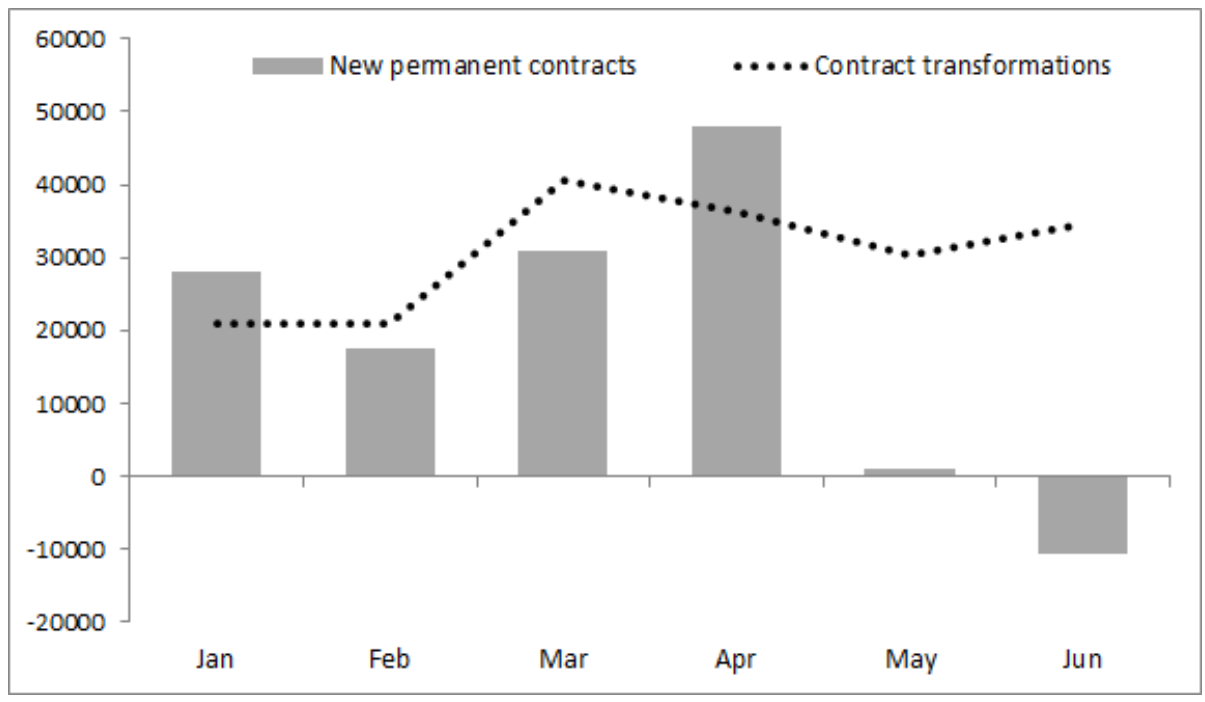

Data source: Ministry of Labour

Moving to the statistical evidence stemming from the Italian Labour Force Survey (LFS), it emerges that the incidence of temporary employment has not

\footnotetext{
${ }^{17}$ Authors computations using data from INPS; see figure 15 in Appendix.

${ }^{18}$ We use data from the Ministry of Labour within this time range since they are homogeneous, while those realized by INPS are not homogeneous due to methodological changes occurred in June and then again in August. Moreover, monthly data from INPS starts only in March.

${ }^{19}$ The incidence of part-time on new permanent contracts is highly above the incidence of total part-time employment as shown in Table2. This difference could be explained by the fact that this detail takes into account only activation, therefore gross of dismissal.

${ }^{20}$ Monthly report, "Osservatorio sul precariato", October 2015.
} 
Table 2: Distribution of new contracts by working time, cumulative data Jan-Sept 2015.

Data source: INPS

\begin{tabular}{rccc}
\hline & \% of Permanent & \% of Temporary & \% of Total \\
\hline FullTime & $59.2 \%$ & $64.2 \%$ & $62.5 \%$ \\
Part Time & $40.8 \%$ & $35.8 \%$ & $37.5 \%$ \\
Total & $100.0 \%$ & $100.0 \%$ & $100.0 \%$ \\
\hline
\end{tabular}

decreased in 2015 and for people aged below 24 years - see figure 3 - its growth rate even increased with respect to the previous years. It is worth noticing that an overall increase in the share of open-ended contracts is observable over a short period of time between late 2014 and yearly 2015. Such trend is detected to be starting before the introduction of both the Jobs Act and the related incentive scheme. Surprisingly, from March 2015 onwards - the period in which the Jobs Act and the incentives under analysis started to propagate their effects - such increasing trend of open-ended contracts begins to be clearly reversed at an even rapid pace. In fact, $63 \%$ of new workers - 158 out of 253 thousands - in the first nine months of 2015 have a temporary contract. A short-run potential explanation of such drop in open-ended contracts - which goes against the declared intentions of both the Jobs Act and the incentive scheme - can be related to the further liberalization in the use of temporary contracts also implied by the Jobs Act. As explained previously, the latter abolishes workers' right to be readmitted into jobs if the fraction of temporary workers over total workforce go beyond imposed limits foreseen by the previous law in force. Overall, the positive trend in the share of temporary contracts goes hand in hand with the weak employment recovery started in 2013 and it seems reinforced during the reform period.

The merge between administrative and LFS data reveals that for each new permanent worker, defined over the stock of total employment, more than nine new contracts have been stipulated with the de-contribution on labour cost, meaning that about only one contract out of 10 survived across months and represents additional employment. In terms of costs, each new permanent worker costs to public finances about 21,000 euros, considering the overall budget spent until now under the scheme (more than two billion euros).

The failure of the Jobs Act in stimulating occupations is confirmed - at least until now - by the transition matrices of the outflow from unemployment between Q1-Q2 2015, according to Eurostat's publication. ${ }^{21}$ Labour market flows for Italy show a huge transition from unemployment into inactivity $(35.7 \%)$, while the transition into employment, regardless the type of contract is lower than the European average (18.6\% vs $16.1 \%$ ) - see figure 9 -.

Furthermore, the weak increase in permanent employment is also unevenly distributed across age cohorts: the decrease in the number of employees in the cohort 15-34 years old is off-set by an equal increase of those belonging to the cohort older than 55 years old. Overall, from a statistical standpoint, the new labour reform do not boost total employment nor standard jobs. Conversely, it seems that the Jobs Act is reducing the unemployment rate of aged workers

\footnotetext{
${ }^{21} \mathrm{http}$ //ec.europa.eu/eurostat/web/products-press-releases/-/3-26102015-AP
} 
Figure 8: Share of temporary and permanent employment on total dependent employment over time

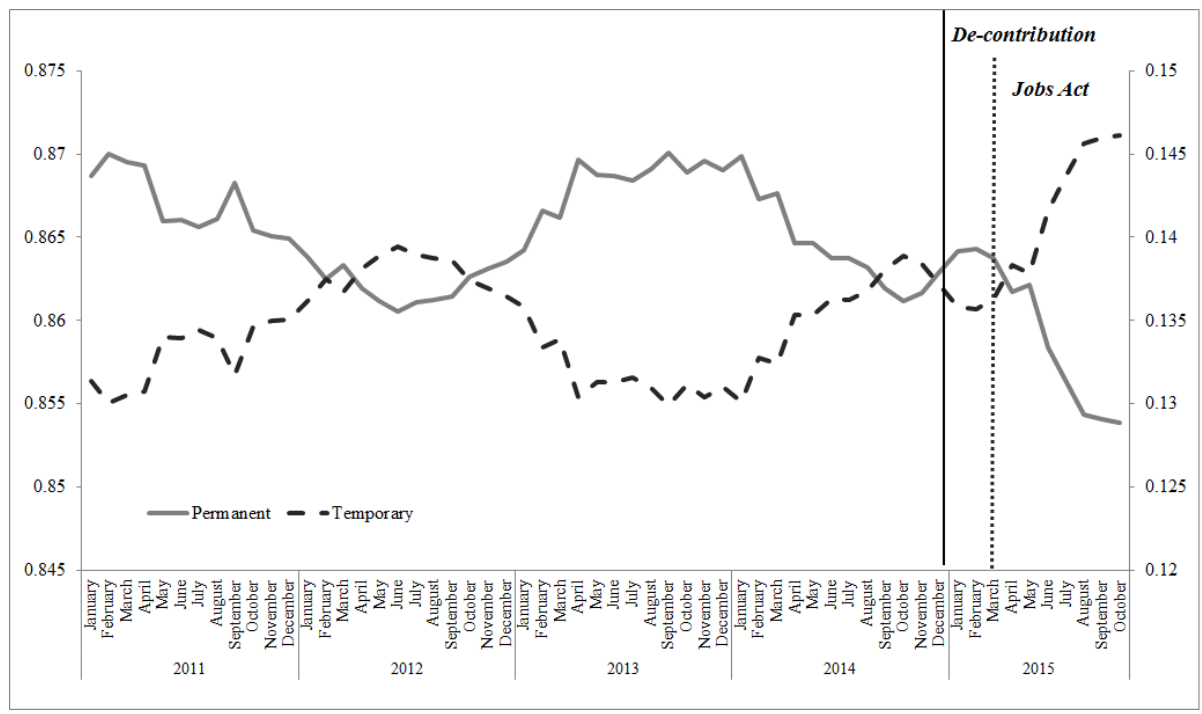

Data Source: Italian Statistical Office - ISTAT

Figure 9: Outflow from unemployment, Q1-Q2 2015 (as \% of unemployed persons aged 15-74 in Q1 2015)

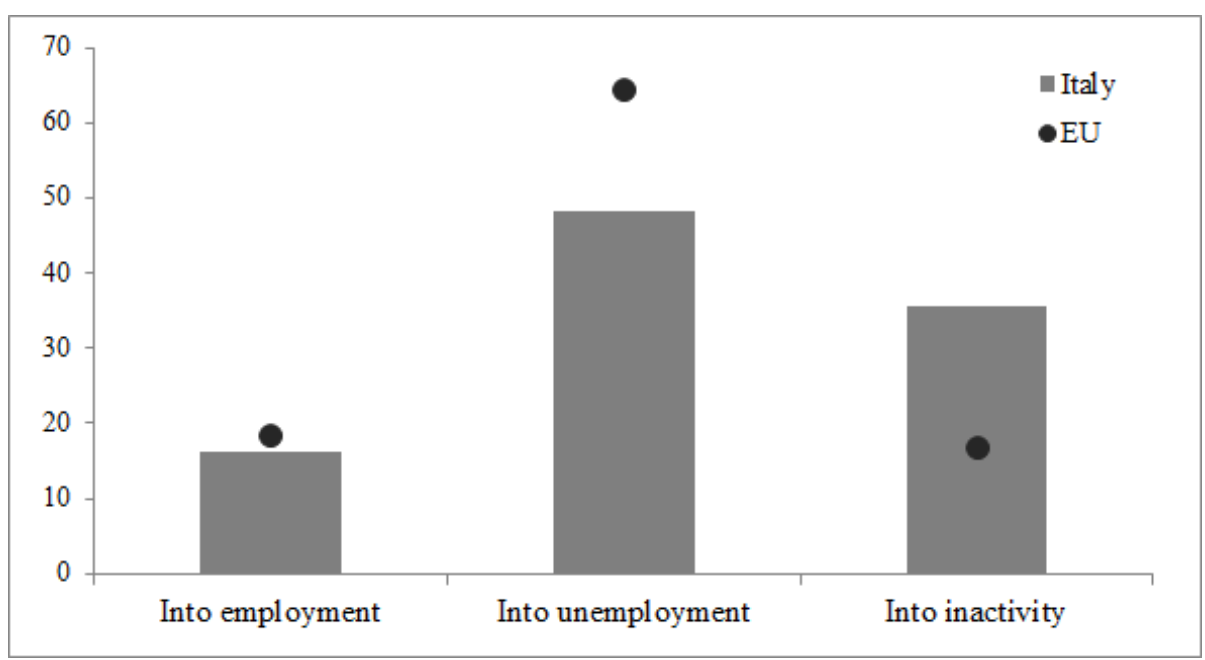

Data source: Eurostat

who cannot retire due to the recently delayed retirement age. ${ }^{22}$

\footnotetext{
${ }^{22}$ The 'Law Fornero' implemented in 2011 modified the Italian pension system significantly postponing the retirement age for both men and women)
} 
In turn, youth employment rate, remains at its lowest level - $15.1 \%$ at the end of the second quarter of 2015 - as it has been shown in section 3, while at the same time the youth unemployment rate decreases - from $43.3 \%$ to $41.1 \%$. However, the decrease in unemployment rate can be hardly attributed to the Jobs Act. In fact, during the same period, the European Youth Guarantee program has been introduced in Italy increasing the youth activity rate. According to data from the Italian Ministry of Labour, 479,424 NEET registered to the employment agencies exit the NEET condition for the unemployed one, pushing down the unemployment rate due to an increase in the active population. ${ }^{23}$

Although data are not as detailed as a rigorous analysis would need, we know that on average jobs posting within the Youth Guarantee program corresponds to temporary positions (see figure 16 in the Appendix) and accounts for one tenth of the labour supply. Assuming that at least parts of these vacancies have been filled over time, this translates in a positive, even if weak, contribution to youth employment. Yet, one third of these vacancies are defined as "technical non professional" occupations, leading to low qualified jobs.

Another feature of the Jobs Act is the further liberalization of less standard job types. Among them, a leading role is played by vouchers, whose upward trend is consolidating over time, as figure 10 shows. Despite this trend do not represents a novelty, since it started already with the first vague of labour market liberalization, this expansion is not slowing down under the Jobs Act. During the first nine months more than 81 millions of 'job tickets' have already been sold, at an annual growth rate equal to $70 \% .^{24}$

Finally, figure 11 shows how job growth is distributed across industries. The manufacturing sector is characterized by a weak recovery in 2014, compared to the same quarters in 2013. However, such slow increase in manufacturing employment early dissipates over time, until a negative or null variation in 2015 - first two quarters. Conversely, the service sector keeps growing since the second half of 2014 onwards, characterized once again by low skill occupations, as already shown in section 3 and in Cirillo and Guarascio (2015). These findings delineate a worrisome picture in structural terms, suggesting the occurrence of a perverse dynamics of structural change featured by a significant reduction in the manufacturing base - which is largely considered crucial to sustain innovation and knowledge diffusion - in favour of an increase of low-tech services, as already noted by Simonazzi et al. (2013) and Stöllinger et al. (2013).

In support of such thesis it is worth underlying that, even under the favourable fiscal treatment, firms do not show any recovered interest in increasing their competitiveness other than through a reduction in labour cost. The acceleration of this process, thus, risks to further undermine productivity and innovation dynamics in the medium-long run (on this point see Landesmann (2013), Mazzucato et al. (2015) and Rodrik (2015)).

\footnotetext{
${ }^{23}$ Source data: Monitoring the Youth Guarantee - Ministry of Labour

${ }^{24}$ The time series of vouchers sold by age groups (see figure 17 in the Appendix), available until 2014, shows that the share of young workers drastically increased over time, while the opposite is true for those older than 55 years old. Not only workers bargaining power is at its minimum under this type of job relationship, but more importantly this evidence highlights the risk for productivity growth.
} 
Figure 10: Number of vouchers sold over time

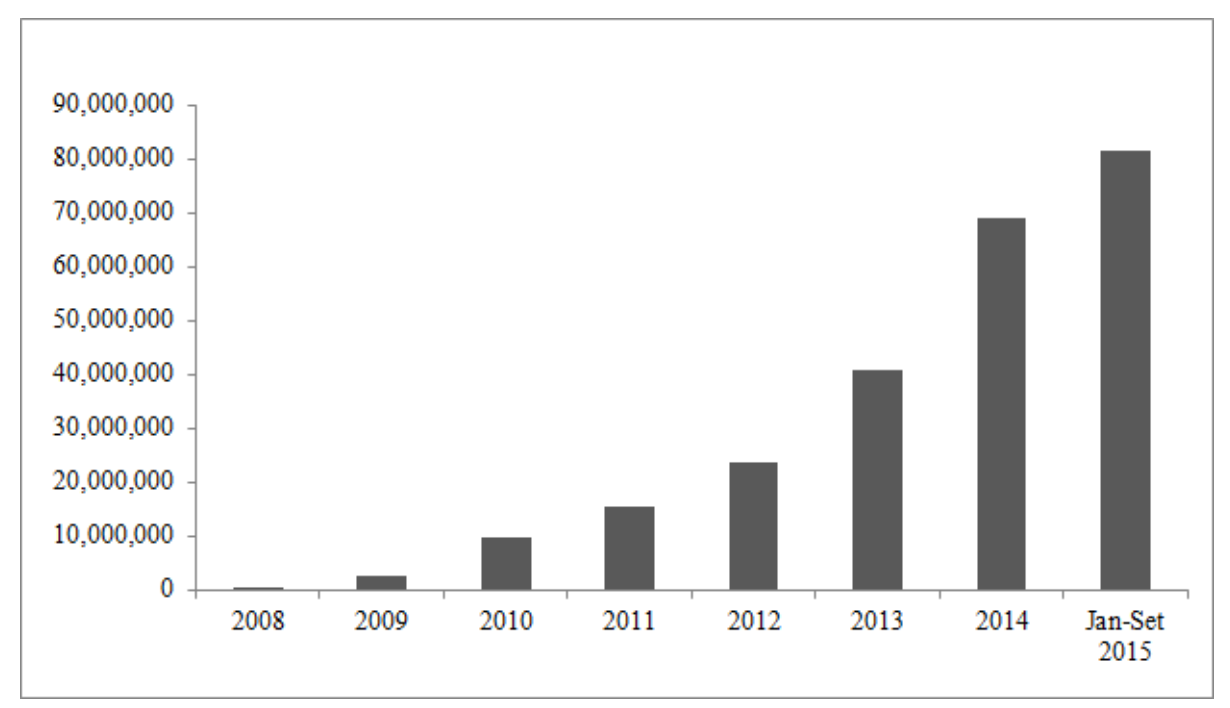

Data source: INPS

Figure 11: New employment across sectors: quarterly variations, seasonally adjusted

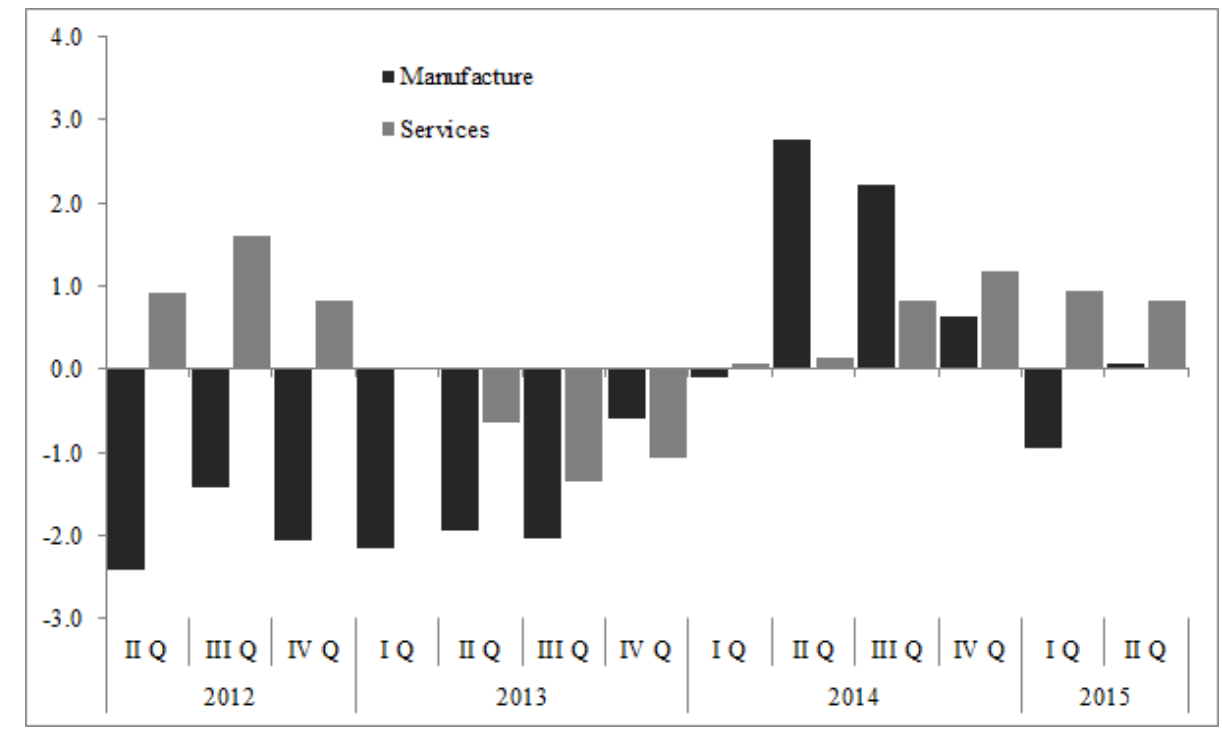

Data source: Italian Statistical Office 


\section{Conclusions and final remarks}

The analysis developed in this article aims at evaluating the impact of the Law 183/2014 - the Jobs Act- on the Italian labour market. After reviewing the related literature and highlighting the arguments in favour and against of labour market deregulation, we framed the Jobs Act's analysis within the overall structural reform process occurred in Italy from the late Nineties onward. The stylized facts provided in section 3 shed light on the poor performances of the Italian labour market- referring, mainly, at employment and labour productivity - over almost the entire investigated period. This weak performance emerged, in particular, concerning the structural diseases historically affecting the Italian economy: the women under representation in the labour market; the persistently high youth unemployment rate; the North-South divide; with the latter structurally lagging behind in terms of employment and production.

The main contribution of this work is presented in section 4 . First we presents an empirical assessment of the Jobs Act by means of all available micro-data. Since a standard policy evaluation is not yet available, due to the lack of counterfactuals, we performed a descriptive analysis to the best of our knowledge, using all relevant data sources (administrative and labour force data). Second, we contextualizes the implementation and the first outcomes of the Law within the Italian economic context, accounting for structural features as well for the 2008's crisis effects.

Results from the empirical exercise show that the Jobs Act is failing in meeting its main goals: boosting employment and reducing the share of temporary and atypical contracts. In fact, as shown through the data inspection, the only increase in employment detected is characterized mainly by temporary contracts signalling that the increase in permanent contracts is mostly due to contracts' transformations and not to jobs creation. In particular, monetary incentives to firms do not seems to translate into new permanent employment but mainly on contracts' transformation from temporary to permanent ones. However, excluding transformations, new permanent contracts, net of dismissal, are only a tiny fraction $(20 \%)$ of total contracts stipulated during the first nine months of 2015 . In terms of working hours, moreover, results show that part-time contracts are more pronounced within new permanent positions than temporary ones, which has mainly an involuntary character.

Labour Force Survey data confirm that the increase in employment during the reform process is weak and mainly due to temporary jobs. In particular, the increase in permanent jobs is characterized by a low productive labour force, once we take into account that only older cohorts (over 55 years old) benefited from the new contract type for standard work during the first nine months. Yet, younger cohorts' employment and changes in inactivity rate appear to be mainly associated to the EYG and the explosion of vouchers, as other administrative data sources indicate. The Jobs Act, in turn, emerge as ineffective in reversing the historically young unemployment rate characterizing the Italian economy. The weak performance of the Jobs Act in creating new employment is also confirmed by LFS data according to which, between the first and second quarter of 2015, Italy is characterized by the outflow from unemployment into inactivity. As a final remark, the Jobs Act seems to have eased in this initial phase the employment shift toward low skilled and low technology sectors. This element is particularly worrisome if linked to the structural effects of the crisis - 
in particular, the significant reduction in productive capacity observed between 2008 and 2013.

In conclusion, it comes out that the analysed combination of supply side policies - the Jobs Act and the provision of indiscriminate monetary incentives for firms hiring with the new contract form - emerged as ineffective in terms of both quantity, quality and duration of the jobs generated. Furthermore, such policies risk to even contribute to the worsening of Italian industrial structure that has accelerated after the 2008 crisis. 


\section{References}

Abraham, K. G. And S. K. Taylor (1993): "Firms' use of outside contractors: Theory and evidence," Tech. rep., National Bureau of Economic Research.

ADDESSI, W. (2014): "The productivity effect of permanent and temporary labor contracts in the Italian manufacturing sector," Economic Modelling, $36,666-672$.

Antonioli, D. And P. Pini (2014): "La crisi del lavoro in Europa e in Italia Per un cambio di rotta," POLITICHE NELLA CRISI, 47.

Armingeon, K. And L. BACCARO (2012): "Do labor market liberalization reforms pay off?" University of Geneva.

Avdagic, S. (2013): "Partisanship, political constraints, and employment protection reforms in an era of austerity," European Political Science Review, 5, $431-455$.

(2015): "Does deregulation work? Reassessing the unemployment effects of employment protection," British Journal of Industrial Relations, 53, 6-26.

Avdagic, S. And C. Crouch (2015): "Symposium Introduction: Labour Market Reforms, Employment Performance, Employment Quality, and Changing Social Risks," British Journal of Industrial Relations, 53, 1-5.

BAKer, D., D. Howell, And J. Schmitt (2005): "Labour market institutions and unemployment," Fighting Unemployment: Limits of Free Market Orthodoxy.

BArbieri, P. AND S. Scherer (2009): "Labour market flexibilization and its consequences in Italy," European Sociological Review, jcp009.

BAssAnini, A. AND E. ERnst (2002): "Labour market institutions, product market regulation, and innovation," .

Battisti, M. And G. VAllanti (2013): "Flexible wage contracts, temporary jobs, and firm performance: Evidence from Italian firms," Industrial Relations: A Journal of Economy and Society, 52, 737-764.

Bentolila, S. And G. Saint-Paul (1994): "A model of labor demand with linear adjustment costs," Labour Economics, 1, 303-326.

Blanchard, O. And P. Portugal (2001): "What hides behind an unemployment rate: comparing Portuguese and US labor markets," American Economic Review, 187-207.

BlANCHARD, O. AND J. WOLFERs (2000): "The role of shocks and institutions in the rise of European unemployment: the aggregate evidence," The Economic Journal, 110, 1-33.

Boeri, T. And P. Garibaldi (2007): "Two Tier Reforms of Employment Protection: a Honeymoon Effect?*," The Economic Journal, 117, F357-F385. 
Calza Bini, P. (2014): "F. Bettio, J. Plantega, M. Smith (eds.), Gender and European Labour Market," Economia 8 lavoro, 48, 191-193.

Cappellari, L., C. Dell'Aringa, And M. Leonardi (2012): "Temporary Employment, Job Flows and Productivity: A Tale of Two Reforms*," The Economic Journal, 122, F188-F215.

Ciriaci, D. And D. Palma (2008): "The role of knowledge-based supply specialisation for competitiveness: A spatial econometric approach*," Papers in Regional Science, 87, 453-475.

Cirillo, V. And D. Guarascio (2015): "Jobs and Competitiveness in a Polarised Europe," Intereconomics, 50, 156-160.

Cirillo, V., M. Pianta, And L. NAscia (2014): "The Shaping of Skills: Wages, Education, Innovation," Tech. rep.

Codogno, L. (2009): "Two Italian Puzzles: are productivity growth and competitiveness really so depressed?" Government of the Italian Republic (Italy)Ministry of Economy and Finance-Department of the Treasury Working Paper Collection.

Damiani, M., F. Pompei, And A. Ricci (2014): "Temporary job protection and productivity growth in EU economies," International Labour Review.

Daveri, F., C. Jona-Lasinio, And F. Zollino (2005): "ITALY'S DECLINE: GETTING THE FACTS RIGHT [with DISCUSSION]," Giornale degli economisti e annali di economia, 365-421.

Elmeskov, J., J. P. Martin, And S. Scarpetta (1998): "Key lessons for labour market reforms: Evidence from OECD countries' experience," Swedish economic policy review, 5.

FAIni, R. AND A. SAPIR (2005): "Un modello obsoleto? Crescita e specializzazione dell'economia italiana," Oltre il declino, Bologna: il Mulino, 19-77.

Glyn, A., D. Baker, D. Howell, And J. Schmitt (2003): Labor market institutions and unemployment: A critical assessment of the cross-country evidence, Department of Economics, University of Oxford.

Holmlund, B. (1998): "Unemployment insurance in theory and practice," The Scandinavian Journal of Economics, 100, 113-141.

Howell, D. R., D. Baker, A. Glyn, And J. Schmitt (2007): "Are protective labor market institutions at the root of unemployment? A critical review of the evidence," Capitalism and Society, 2.

Hurley, J., E. Fernandez-Macias, And D. Storrie (2013): "Employment Polarization and Job Quality in the Crisis," .

Jona-Lasinio, C. And G. VAllanti (2013): "Reforms, labour market functioning and productivity dynamics: a sectoral analysis for Italy," Government of the Italian Republic (Italy), Ministry of Economy and Finance, Department of the Treasury Working Paper. 
KLEInKNeCht, A. (1998): "Is labour market flexibility harmful to innovation?" Cambridge Journal of Economics, 387-396.

Kleinknecht, A., F. N. van Schaik, and H. Zhou (2014): "Is flexible labour good for innovation? Evidence from firm-level data," Cambridge Journal of Economics, 38, 1207-1219.

Landesmann, M. (2013): "The New North-South Divide in Europe: Can the European Convergence Model be Resuscitated?" Vienna Institute Monthly Report, 1.

Lazear, E. P. (1990): "Job security provisions and employment," The Quarterly Journal of Economics, 699-726.

Lucchese, M. And M. Pianta (2012): "Innovation and employment in economic cycles," Comparative Economic Studies, 54, 341-359.

LuCidi, F. And A. Kleinknecht (2009): "Little innovation, many jobs: An econometric analysis of the Italian labour productivity crisis," Cambridge Journal of Economics, bep011.

Malgarini, M., M. Mancini, and L. Pacelli (2013): "Temporary hires and innovative investments," Applied Economics, 45, 2361-2370.

Mancini, M. (2007): "Regimi di protezione all'impiego ed effetti sul mercato del lavoro: l'evoluzione della flessibilità in Italia," I Temi dei Rapporti ISAE, June.

Mazzucato, M., M. Cimoli, G. Dosi, J. E. Stiglitz, M. A. Landesmann, M. Pianta, R. Walz, AND T. PAGe (2015): "Which industrial policy does Europe need?" Intereconomics, 50, 120-155.

Nickell, S., L. Nunziata, And W. Ochel (2005): "Unemployment in the OECD Since the 1960s. What Do We Know?*," The Economic Journal, 115, $1-27$.

NoelKe, C. (2011): "The consequences of employment protection legislation for the youth labour market," MZSE AP, 144.

OECD (1994): "The OECD Job Study," Paris:OECD, 1994.

Oesch, D. (2010): "What explains high unemployment among low-skilled workers? Evidence from 21 OECD countries," European Journal of Industrial Relations, 16, 39-55.

Pini, P. (2012): "La non-riforma del mercato del lavoro italiano," Tech. rep.

_ (2014): "Quaderno DEM 18/2014 Note di policy," .

RodRIK, D. (2015): "Premature Deindustrialization," Working Paper 20935, National Bureau of Economic Research.

Saint-Paul, G. (2004): "Why are European countries diverging in their unemployment experience?" . 
Saltari, E. AND G. Travaglini (2008): "Il rallentamento della produttivita'del lavoro e la crescita dell'occupazione. Il ruolo del progresso tecnologico e della flessibilita'del lavoro," Rivista italiana degli economisti, 13, 338 .

SCARPETTA, S. (1996): "Assessing the role of labour market policies and institutional settings on unemployment: A cross-country study," OECD Economic studies, 26, 43-98.

Scarpetta, S. And T. Tressel (2004): "Boosting productivity via innovation and adoption of new technologies: any role for labor market institutions?" World Bank Working Paper.

Siebert, H. (1997): "Labor market rigidities: at the root of unemployment in Europe," The Journal of Economic Perspectives, 37-54.

Simonazzi, A., A. Ginzburg, And G. Nocella (2013): "Economic relations between Germany and southern Europe," Cambridge Journal of Economics, $37,653-675$.

Stöllinger, R., N. Foster-McGregor, M. Holzner, M. Landesmann, J. Pöschl, R. Stehrer, And C. Stocker-Waldhuber (2013): A" manufacturing Imperative" in the EU: Europe's Position in Global Manufacturing and the Role of Industrial Policy, Verein" Wiener Inst. für Internat. Wirtschaftsvergleiche"(WIIW).

Vergeer, R. And A. Kleinknecht (2012): "Do flexible labor markets indeed reduce unemployment? A robustness check," Review of Social Economy, 70, 451-467.

(2014): "Do labour market reforms reduce labour productivity growth? A panel data analysis of 20 OECD countries (1960-2004)," International Labour Review, 153, 365-393. 


\section{Appendix}

Figure 12: Outflow from unemployment into inactivity (as \% of unemployment persons), 2010Q3-2015Q2

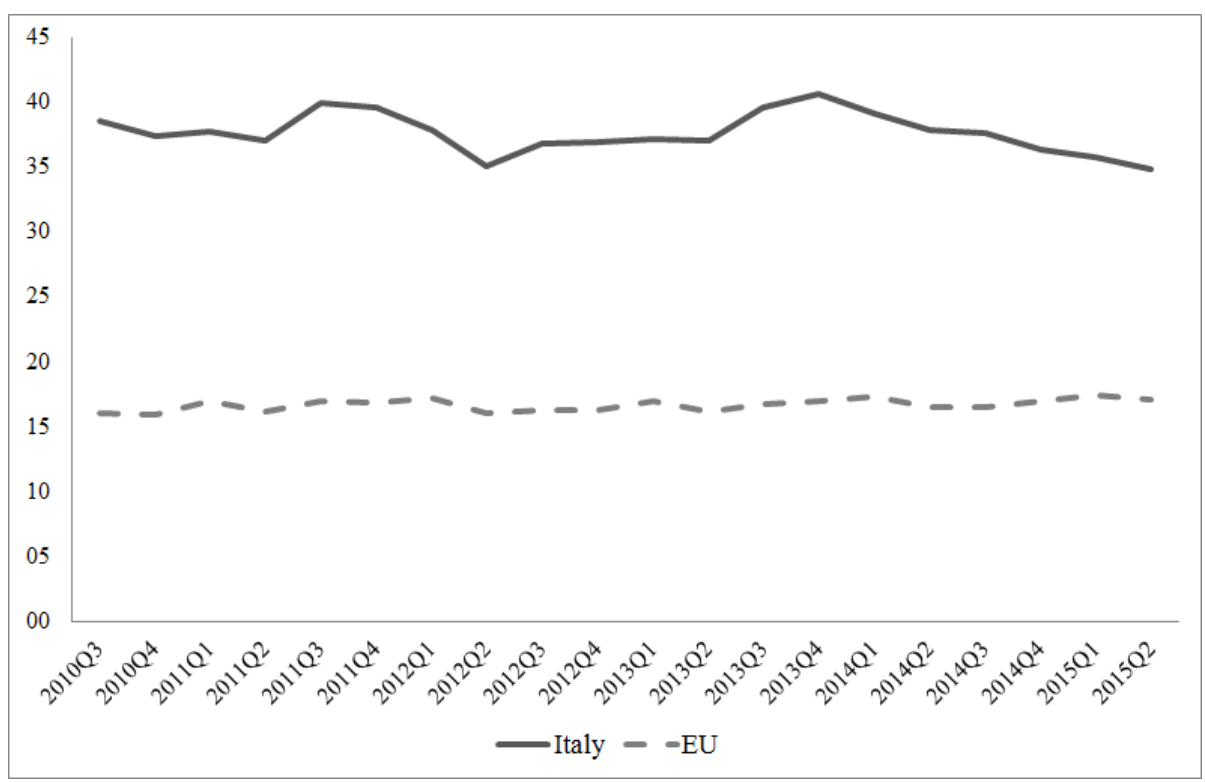

Data source: Eurostat 
Figure 13: Outflow from unemployment into employment (as \% of unemployment persons), 2010Q2-2015Q2

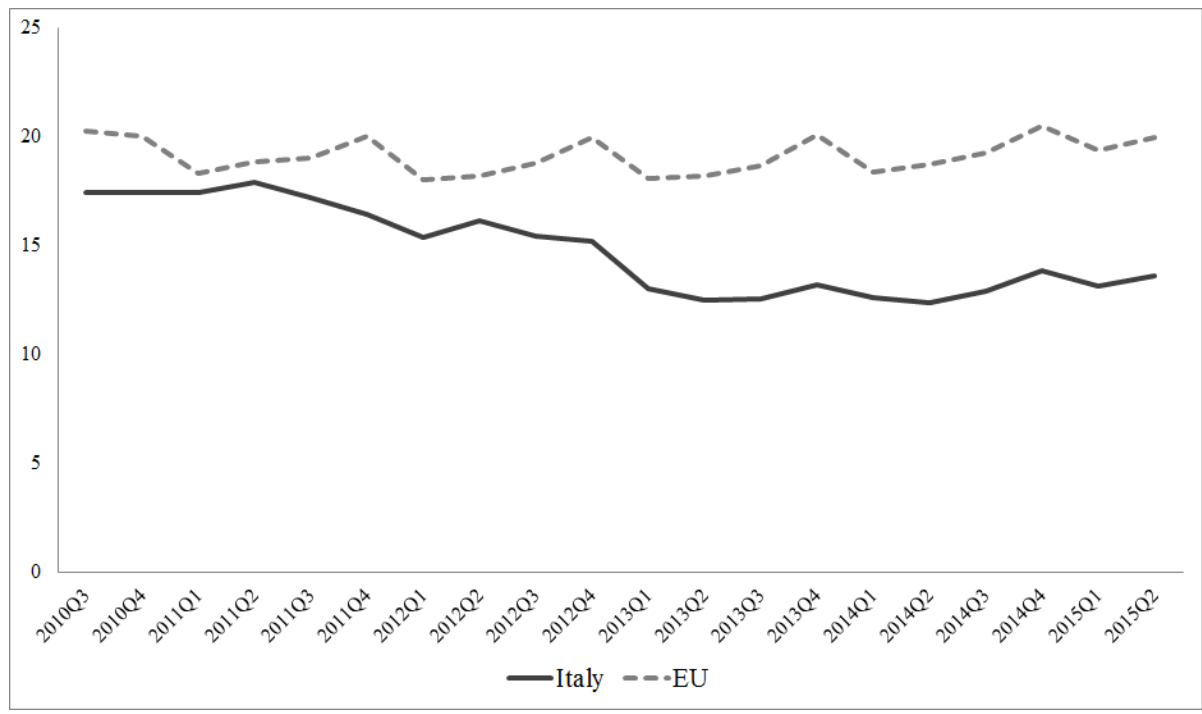

Data source: Eurostat

Figure 14: Labour productivity - annual rate of change Data source: STAN OECD

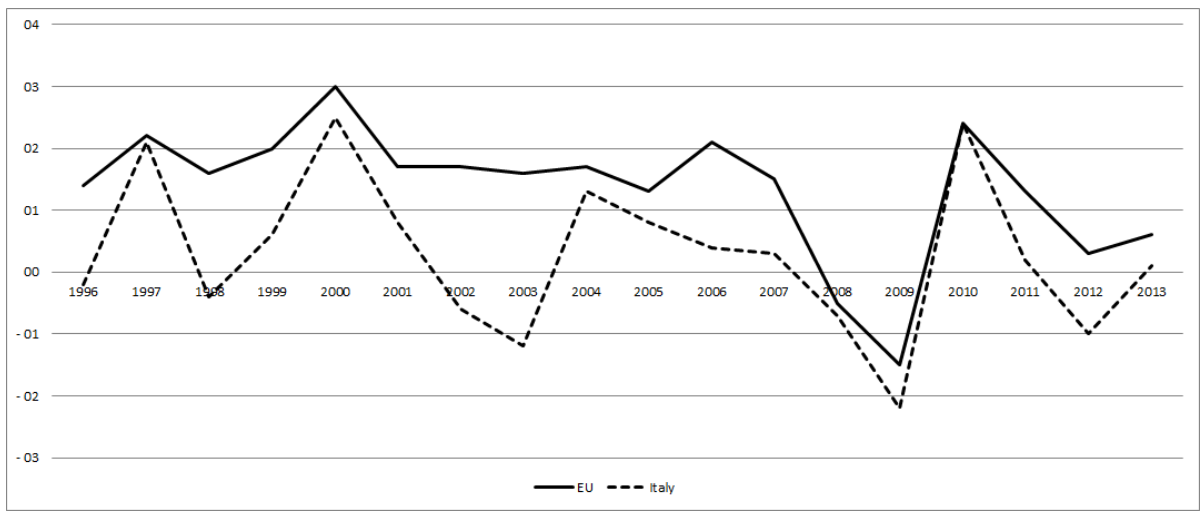


Figure 15: share of R\&D on GDP (OECD)

Data source: STAN OECD

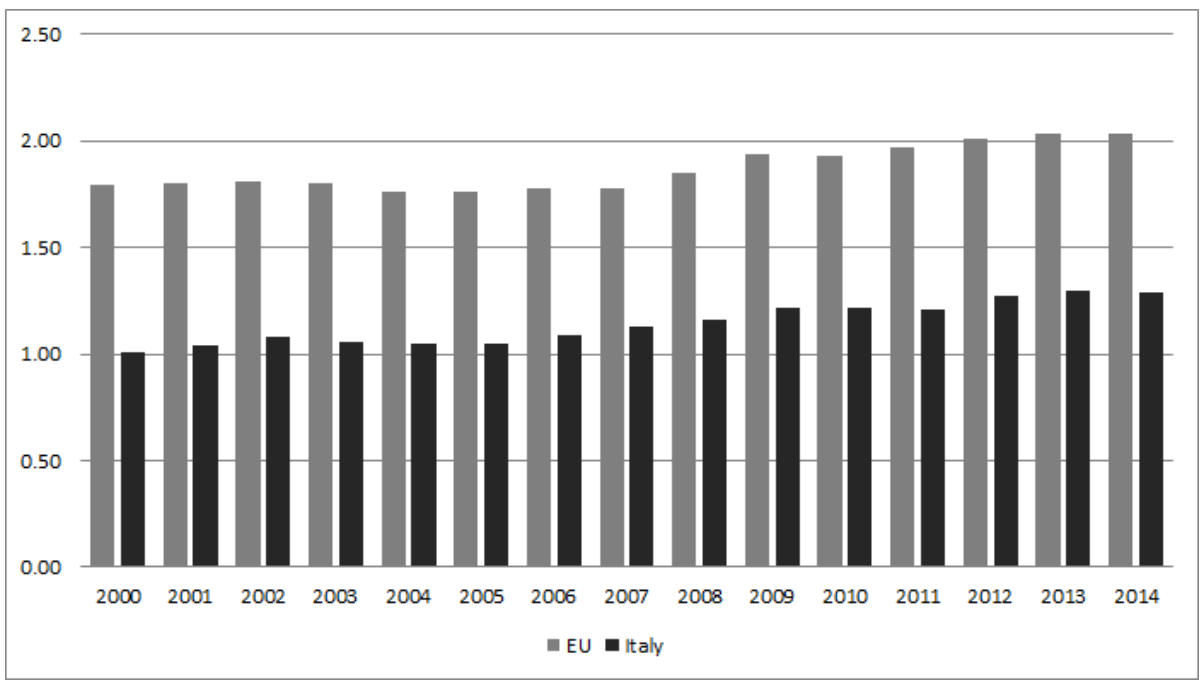

Figure 16: Distribution of contracts by type, Jan-Sept2015 Data source: INPS

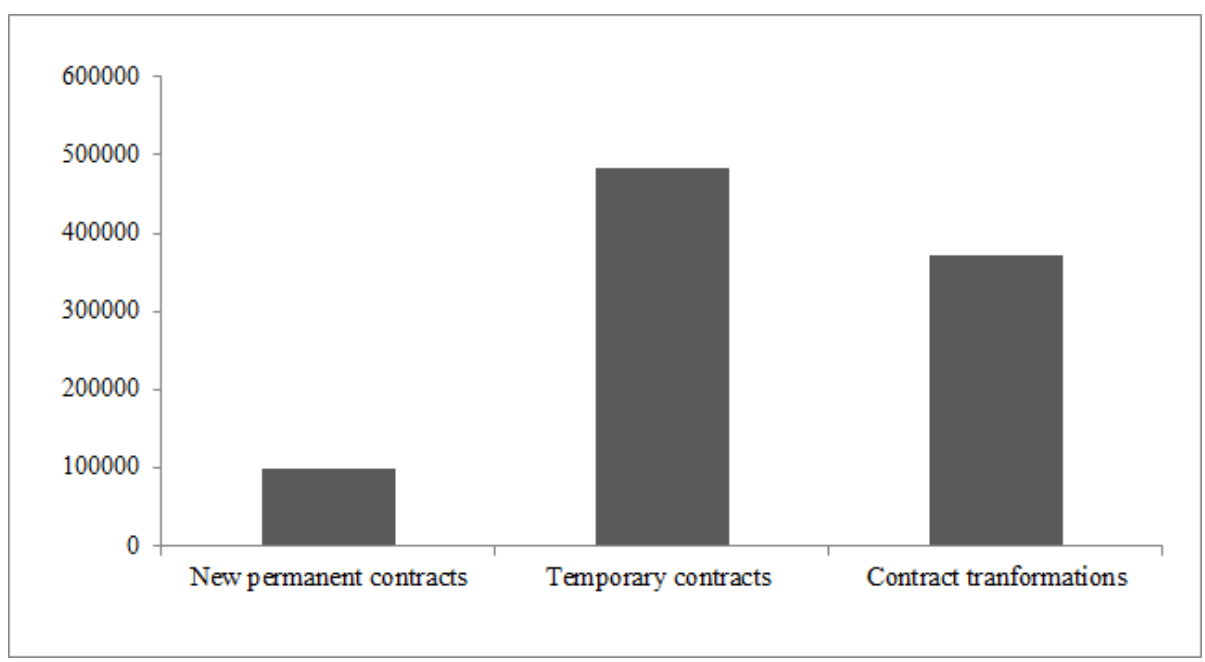


Figure 17: Vacancies by type of contract under the Youth Guarantee Jan-Sept2015)

Data source: INPS

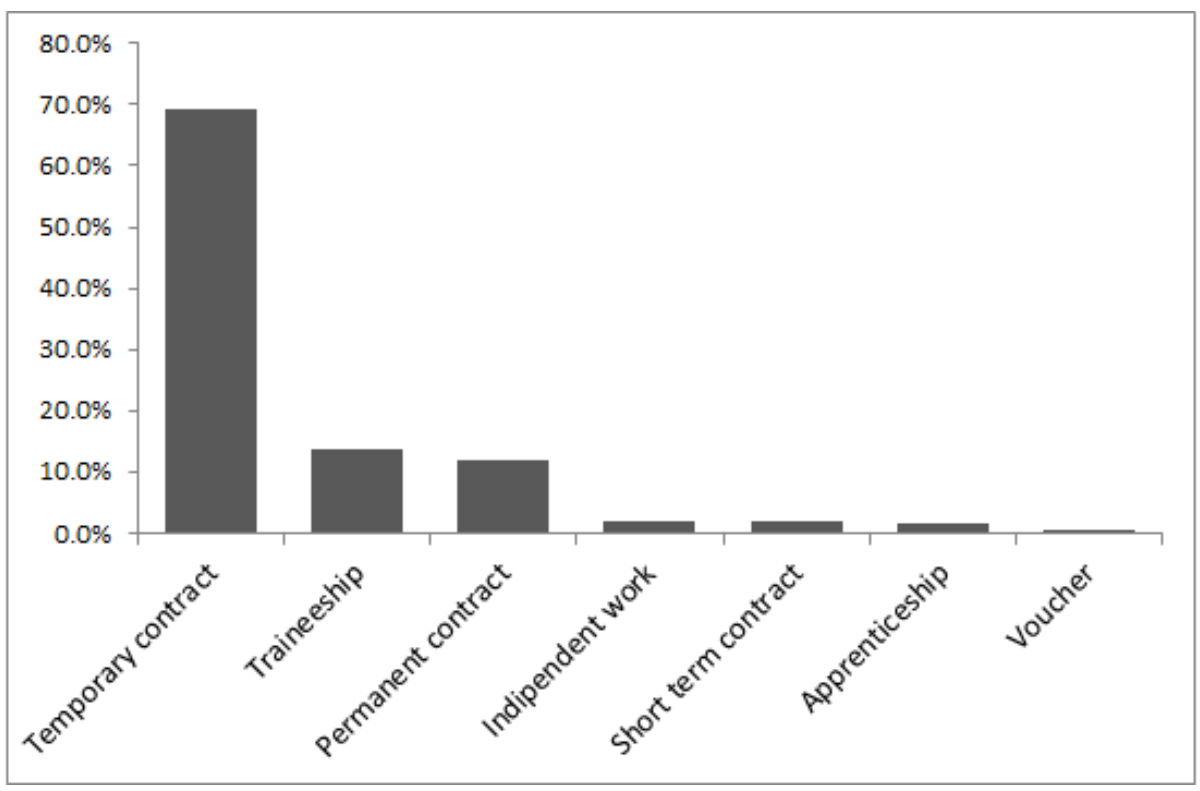

Figure 18: Workers with vouchers by age group

Data source: INPS

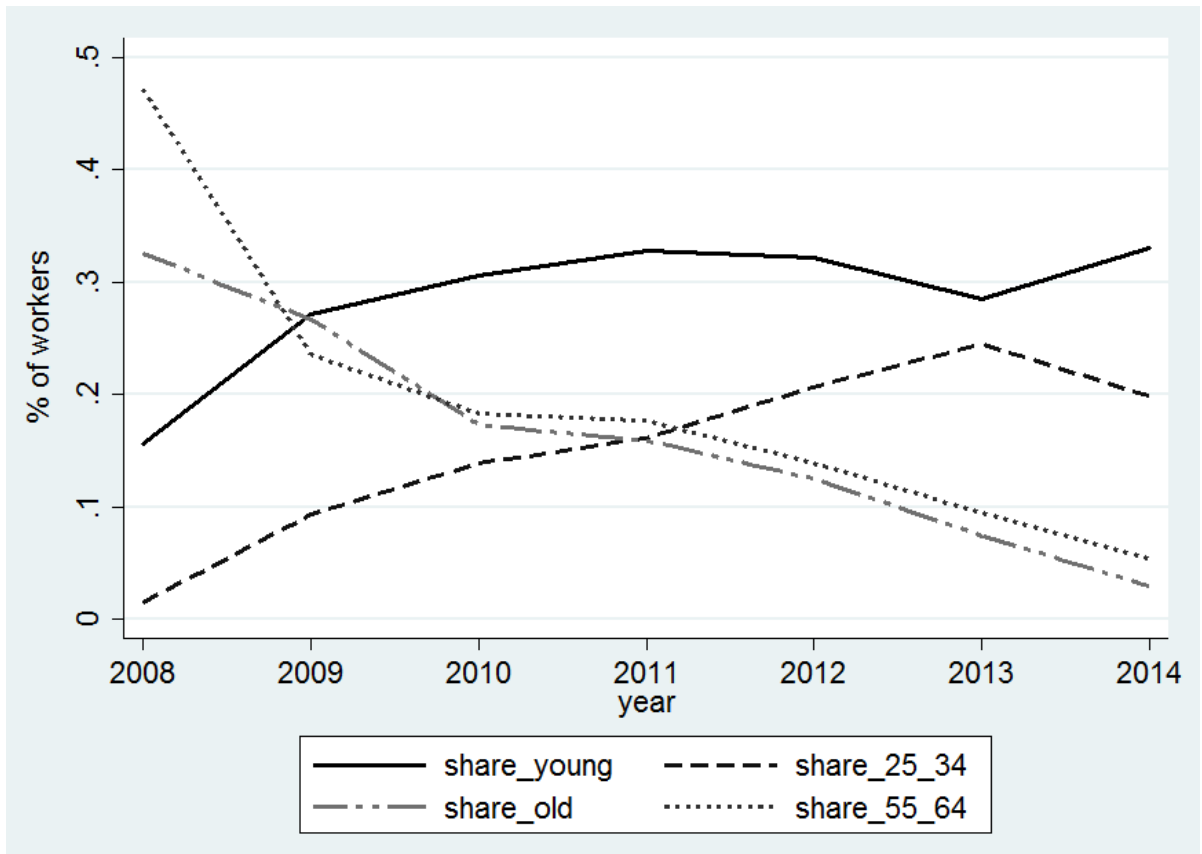

